\title{
Informal Institutions and Corporate Reputational Exposure: The Role of Public Environmental Perceptions
}

\author{
Chrysovalantis Gaganis, ${ }^{1}$ Panagiota Papadimitri, ${ }^{2}$ Fotios Pasiouras ${ }^{3}$ \\ and Alexia Ventouri (D) 4 \\ ${ }^{1}$ Department of Economics, University of Crete, Rethymno, 74100, Greece, ${ }^{2}$ Portsmouth Business School, \\ University of Portsmouth, Portland Street, Portsmouth, PO1 3AH, UK, ${ }^{3}$ Department of Financial \\ Management, Law \& Accounting, Montpellier Business School, 2300 Avenue des Moulins, Cedex 4, \\ Montpellier, 34185, France, and ${ }^{4}$ King's Business School, King's College London, 30 Aldwych, London, WC2B \\ 4BG, UK \\ Corresponding author email: alexia.ventouri@kcl.ac.uk
}

\begin{abstract}
Public awareness about issues surrounding the physical environment and climate change is becoming more important around the world. However, there is a lack of research on the association between environment-related perceptions and reputational exposure. Therefore, we know little about whether and how reputational exposure is shaped by institutional pressures, as would be stipulated by institutional theory. Using a sample of 643 firms from 19 European countries over the period 2015-2018, we aim to shed further light on this issue. Our results show that more environmentally friendly public perceptions result in lower reputational exposure. This finding holds when, on an individual basis, we examine public opinions on energy, climate and the introduction of related policies. To ensure robustness in our results, we conduct a number of analyses and tests designed to alleviate endogeneity and correct sample bias.
\end{abstract}

\section{Introduction}

We would like to thank Konstantinos Stathopoulos (discussant) and other participants at the Essex conference 'Corporate Governance in Changing Institutional Environments' for valuable comments. Thanks are also due to participants at the 9th International Conference of the $\mathrm{Fi}$ nancial Engineering and Banking Society (Prague, 2019), the 9th National Conference of the Financial Engineering and Banking Society (Athens, 2018) and the King's Business School seminar series. Alexia Ventouri acknowledges the internal research fund from King's Business School. Fotios Pasiouras thanks Montpellier Business School (MBS), a founding member of the public research centre Montpellier Research in Management, MRM (EA 4557, Univ. Montpellier). We are also grateful to Douglas Cumming (Co-Editor-in-Chief), Claudia Girardone (Guest Editor) and the three anonymous reviewers. This paper was under review for the Corporate Governance in Extreme Institutional Environments special issue and went through three rounds of revisions. Any remaining errors are our own.
In recent years, policy-makers have introduced various initiatives to address environmental concerns and to combat climate change. These often take the form of pressures from a formal institutional environment, like environmental courts and regulations, which can in turn be associated with higher costs and lower profits for firms (Berkman, Jona and Soderstrom, 2019; Zhang, $\mathrm{Yu}$ and Kong, 2019), putting pressure on managers. ${ }^{1}$ For example, Mark Carney (2019) highlights that the global transition needed to tackle the climate crisis could result in an abrupt

\footnotetext{
${ }^{1}$ Well-known examples of policy-making initiatives are the Kyoto Protocol, the European Union Emissions Trading Scheme and the Paris Agreement.
} 
financial collapse, as firms struggle to operate under extreme shifts in the institutional environment. Additionally, managers face further pressure from informal institutions, like social norms and beliefs that enhance public awareness of how firms' activities can have an impact on the physical environment and climate change. Arguably, therefore, firms now operate within an extreme institutional environment where they must balance the interests of shareholders with those of other stakeholder groups. While some recent studies have examined the impact of formal environment-related institutions on firm outcomes (Shi and Xu, 2018; Zhang, Yu and Kong, 2019), less attention has been given to the role of informal institutions. Accordingly, this study examines whether informal institutions impact public perceptions of environmental issues and how such perceptions influence corporate reputation.

Corporate reputation and the associated risks have received much attention from academics and practitioners, illustrating their relationship to market value (Black, Carnes and Richardson, 2000; Weber Shandwick and KRC Research, 2020), perceived importance for executives (Deloitte, 2014) and association with better firm outcomes (e.g. Cao et al., 2015; Roberts and Dowling, 2002). Nonetheless, evidence suggests that only a small proportion of firms feel capable of managing reputational risk (Deloitte, 2014), which might be explained by poor understanding of its sources and how to measure it (Deloitte, 2016).

Therefore, a question that naturally emerges is what drives reputation and reputational risk. Today, most of our knowledge comes from countryspecific studies (mainly focused on the USA) that analyse firm-specific and industry-specific factors like financial performance, size and popular management techniques (Staw and Epstein, 2000), downsizing (Zyglidopoulos, 2005), board characteristics (Musteen, Dattal and Kemmerer, 2010), social performance and the nature of business activities (Brammer and Pavelin, 2006; Nardella, Brammer and Surdu, 2019). In other words, as discussed by Soleimani, Schneper and Newburry (2014), the reputation literature often implicitly treats the driving factors of firm reputation as fixed and universal across countries, while the impact of national institutions on corporate reputation assessment has received comparatively less attention and is still not fully understood. Gardberg (2006) emphasizes that since cor- porate reputation is a social variable in an open system, varying regulatory, normative and cognitive elements of national institutional environments may affect corporate reputation construction and expectations, and thus its international generalizability.

As little is known about the country-level drivers of reputational assessments (Soleimani, Schneper and Newburry, 2014), this study extends the literature on corporate reputational rankings (e.g. Bermiss, Zajac and King, 2014) by examining how public perceptions of environmental issues affect reputational risk. Our analysis is based on institutional theory, which has been widely adopted to explain how firm behaviour is driven by institutional pressures. Despite the wide adoption of institutional theory in studies of environmental management practices (Berrone et al., 2013; Daddi et al., 2016), corporate social responsibility (Brammer, Jackson and Matten, 2012), sustainable practices (Glover et al., 2014) and climate change strategies (Daddi et al., 2016), there has been little empirical investigation of the institutional drivers of reputation (see e.g. Deephouse, Newburry and Soleimani, 2016; Soleimani, Schneper and Newburry, 2014), and no study of the association between environment-related perceptions of the public and reputational exposure. Building on neo-institutionalism theory and upper echelons theory, we also examine the conditional role of the background characteristics of company directors. Thus, we make two contributions to the literature. First, as we discuss in detail in the next section, the impact of public perceptions on environmental issues and reputational exposure is ambiguous, as it could be either positive or negative. This remains an open question to be answered empirically, and we present the first systematic analysis of this issue in a cross-country setting. This is not only a matter of using a large international sample. Most importantly, it allows us to examine whether countrylevel characteristics, like formal institutions (e.g. rule of law, regulatory quality), moderate this relationship. Second, we examine the conditional role of an array of firm-level corporate governance characteristics, like CEO nationality, board age diversity, board qualifications, board nationality mix and board gender mix. Our findings could be of interest to various groups. First, as we present new empirical evidence, they could be of interest to scholars on corporate reputation, corporate governance and institutional theory. Second, as 


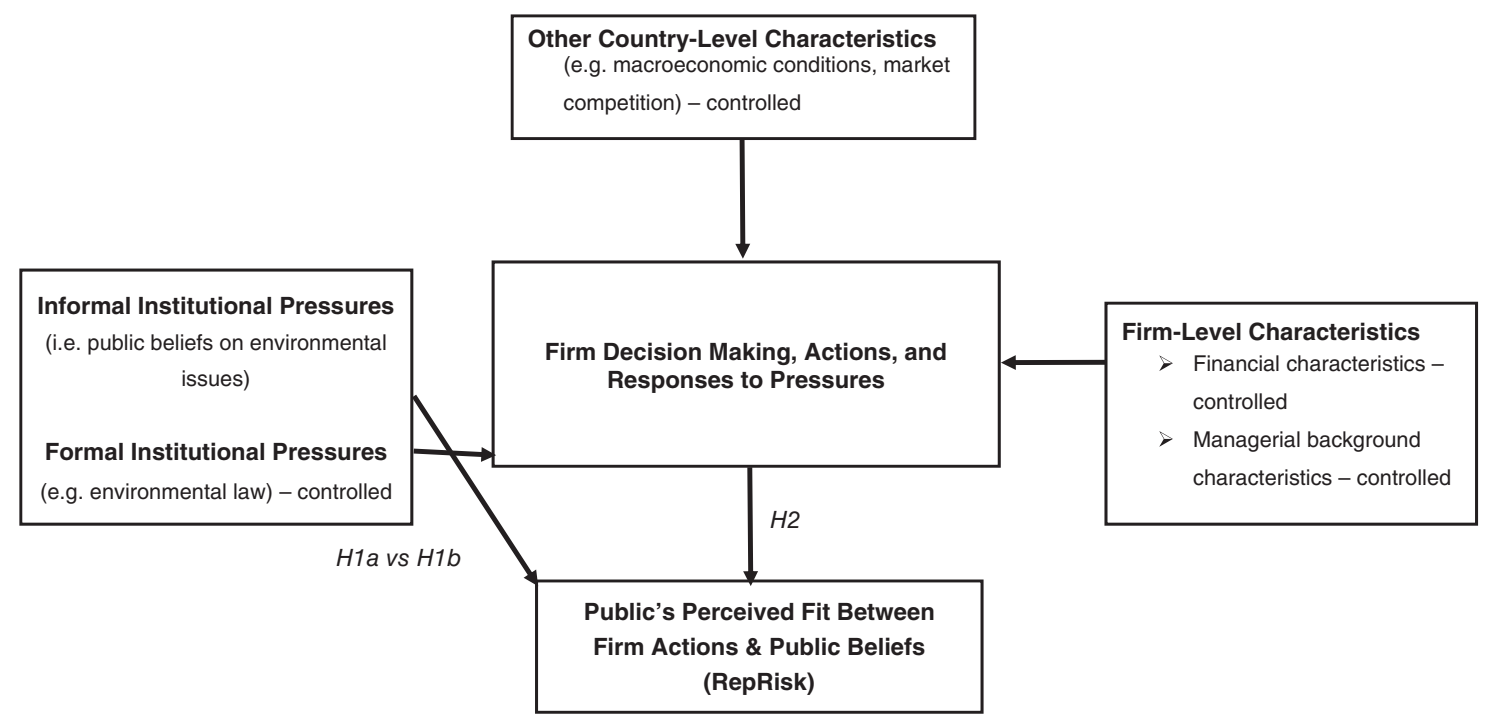

Figure 1. Conceptual framework: informal institutional pressures and corporate reputation

we discuss in more detail, they could be of interest to firm stakeholders like policy-makers, managers, shareholders and prospective investors.

The rest of this paper is structured as follows. The following section discusses the theoretical background and develops the hypotheses. The third section then outlines the data and methodology. The fourth section reports the results. Finally, the last section discusses our findings and concludes.

\section{Institutional theory and reputation}

Institutional theory emphasizes how the social and cultural pressures imposed on organizations influence their practices and structures (Scott, 1992). Central to this theory is the idea that many aspects of organizations are driven by the desire to achieve fit with the institutional environment. This fit has been defined as 'the degree of compliance by an organisation with the organisational form of structures, routines, and systems prescribed by institutional norms' (Kondra and Hinings, 1998, p. 750). Thus, institutional theory appears integral to the concept of corporate reputation, which represents the collective evaluation by stakeholders of a firm's goals, values and behaviour compared to those of other firms and to the stakeholders' own expectations (Deephouse, Newburry and Soleimani, 2016; Mishina, Block and Mannor, 2012). Within the same context,
Soleimani, Schneper and Newburry (2014) highlight that corporate reputation depends on the extent to which firm behaviour conforms with socially constructed beliefs about which goals and objectives should be pursued. Figure 1 outlines our research framework and hypotheses, which we discuss in more detail below.

The traditional view of institutional theory asserts that institutional isomorphism makes organizations quite similar, through a process that leads them to adopt similar forms and practices (DiMaggio and Powell, 1983), and consequently promotes the success and survival of organizations (Meyer and Rowan, 1977). ${ }^{2}$ Within this context, Oliver (1991) highlights that the self-serving advantages of compliance with institutional norms and requirements are illustrated by the claimed association between organizational conformity and

\footnotetext{
${ }^{2}$ DiMaggio and Powell (1983) distinguish between three mechanisms through which institutional isomorphic change occurs. The first is coercive isomorphism that stems from political influence and the problem of legitimacy. This results from both formal and informal (e.g. cultural expectations) pressures on organizations. The second mechanism is mimetic isomorphism resulting from standard responses to uncertainty. In this case, organizations adopt mimetic behaviours and tend to model themselves on similar organizations in their field that they perceive as more legitimate or successful. The third mechanism is normative isomorphism, associated with professionalization. Nonetheless, DiMaggio and Powell (1983) also recognize that this typology is analytic and that these types are not always empirically distinct.
} 
the various rewards discussed in the institutional literature, including increased prestige. Wright and Rwabizambuga (2006) also argue that 'firms are rewarded with enhanced legitimacy and reputation if they develop internal structures "isomorphic" with external institutional pressures' ( $p$. 90). In general, this traditional view of institutional isomorphism and organizational similarities implies that managerial and other firm-level characteristics do not have an important role. For example, according to Oliver (1991), 'institutional theory illustrates how the exercise of strategic choice may be pre-empted when organisations are unconscious of, blind to, or otherwise take for granted the institutional process to which they adhere' (p. 148). Moreover, 'In the face of very widely shared and taken-for-granted understandings of what constitutes legitimate or rational behaviour, organisations will conform largely because it does not occur to them to do otherwise' (Oliver, 1991, p. 169). Along the same lines, Suchman (1995) argues that external institutions, like culture, construct and interpenetrate the organization in every respect. Therefore, the decisions of the managers are often constructed by the same belief systems that determine the reactions of the audience. This leads to a high degree of convergence between institutionalization and legitimacy.

Based on the above discussion, we expect that societal beliefs about the environment will have a direct impact on reputation. Firms have no option but to be institutionalized and behave in accordance with public expectations. With the consequential narrowing of the gap between broader societal expectations and the effects of corporate practices that can challenge the legitimacy and reputation of individual firms, reputational exposure will decline. Therefore, we formulate the first hypothesis as follows:

H1a There is a negative relationship between environmentally friendly societal beliefs and corporate reputational exposure.

However, various neo-institutionalism studies (Walls and Hoffman, 2013) argue that firms may respond heterogeneously when subjected to a homogenous level of institutional pressures (Aharonson and Bort, 2015; Oliver, 1991; Wang, Li and Zhao, 2018). At the same time, societies with more environmentally friendly societal beliefs tend to set higher standards for their companies, and therefore firms face a greater risk of falling short of the expectations. In more detail, organizations must devote resources towards environmental initiatives in a way that simultaneously satisfies their economic objectives (Hoffman, 2001). This might conflict with pressures from shareholders to increase profitability. As Oliver (1991) considers, an organization whose performance and survival only moderately depend upon good public opinion might choose avoidance tactics in response to institutional rules and expectations. Within the same context, Chen et al. (2018) mention that high expenditure and unclear future benefit make some firms reluctant to engage in green innovation, even when faced with strong institutional pressures. They also note that institutional pressures are coercive in nature, driven by the threat of either legal sanction or social sanction, like protests, negative press and diminished reputation and image.

Consequently, it is possible that higher expectations are more likely to be violated by firms, leading to poor institutional fit, public criticism and higher reputational exposure. Thus, under this scenario we would expect to find a positive association between public environmental perceptions and corporate reputational exposure. Hence, we formulate the alternative first hypothesis as follows:

$\mathrm{H} 1 \mathrm{~b}$ There is a positive relationship between environmentally friendly societal beliefs and corporate reputational exposure.

Another issue recently discussed in the literature is that the response to institutional pressures depends upon managerial factors. For instance, Walls and Hoffman (2013) propose that the variance in organizational actions towards environmental sustainability depends primarily on the direction set by the board. Wang, Li and Zhao (2018) find that top management's environmental commitment moderates the relationship between institutional pressures and environmental management practices. Along the same lines, focusing on institutional pressures on corporate climate change strategies, Daddi et al. (2020) conclude that companies with higher managerial sensitivity to climate change are more likely to adopt both mitigation and adaption strategies. González-Benito and González-Benito (2008) highlight the role of managers' ability and willingness to monitor and listen to stakeholders' environmental demands. As they 
discuss, even if stakeholder demands are clearly specified (which is not always the case), managers might differ in their level of attention and ascribed importance. In some cases, managers might overstate the consequences of ignoring such demands; in other cases, they could underestimate them. These arguments and findings appear to be in line with upper echelons theory, which states that organizational outcomes, including both strategic choices and performance levels, are partially predicted by the background characteristics of the top management team (Hambrick and Mason, 1984). Therefore, we formulate the second hypothesis as follows:

H2 Background characteristics of the board of directors moderate the relationship between environmentally friendly societal beliefs and corporate reputational exposure.

\section{Data and methodology}

\section{Data}

To examine whether public perceptions on environmental issues impact on reputational exposure, we use information from various sources. To quantify reputational exposure, we use the ratings of reputational risk related to environmental, social and governance (ESG) issues provided by RepRisk. ${ }^{3}$ Data on public perceptions of environmental issues are sourced from the European Social Survey (ESS). ${ }^{4}$ Firm-specific charac-

\footnotetext{
${ }^{3}$ RepRisk was formed in 1998 as ECOFACT, an environmental and social risk consultancy. In 2006, in response to a request by UBS, RepRisk developed a proprietary, systematic framework to identify and assess companies exposed to ESG risks. In 2007 it launched a fully fledged web-based tool, the RepRisk ESG Risk Platform. Over the years it gained popularity in the market and is currently used by, among others, RobecoSAM in the annual corporate assessment process for the Dow Jones Sustainability Index, the Investment Engagement team of the UN-supported Principles for Responsible Investment and CDP (formerly the Carbon Disclosure Project) in its annual review of companies identified as 'carbon performance leaders' or 'water performance leaders'.

${ }^{4}$ The European Social Survey (ESS) is an academically driven cross-national survey that has been conducted across Europe since 2001. Every 2 years, face-to-face interviews are conducted to measure the attitudes, beliefs and behaviour patterns of diverse populations in around 30 European countries. In this study, we capture public perceptions based on data provided by Round 8 of the ESS (2016): http://www.europeansocialsurvey.org/data.
}

teristics are collected from Datastream. Finally, data on country-related variables are sourced from the World Bank (WB), World Economic Forum (WEF) and the Regulatory Indicators for Sustainable Energy (RISE). Our sample comprises 643 firms operating in 19 countries $^{5}$ and across 18 industries $^{6}$ over the period $2015-2018 .^{7}$ This results in a final balanced panel dataset of 2,372 firm-year observations. The data sources and all the variables are described in Table 1 . Table 2 summarizes the distribution of firm observations per country. ${ }^{8}$

\section{Variables}

Dependent variable: Reputational exposure rating. The dependent variable is Reputational exposure rating, an indicator of ESG-related reputational risk maintained by the business intelligence provider RepRisk. The rating assesses the ESG risk exposure of companies worldwide by systematically capturing negative incidents, criticism and controversies on a daily basis from over 80,000 media outlets, stakeholders and third-party sources in 20 languages; these sources include all major print and online media, non-governmental organizations, regulators, news sites, governmental agencies and social media. ${ }^{9}$ RepRisk gathers data through a five-step process: (i) screening; (ii) identification and filtering; (iii) analysis; (iv) quality assurance; and (v) quantification. Once an incident is identified, the analysis includes verification of its type and nature, as well as classification into one or more of the 28 predefined ESG categories. RepRisk argues that its analysis is issuesdriven, rather than firm-driven, and so does not

\footnotetext{
${ }^{5}$ Countries included in the sample: Austria, Belgium, Czech Republic, Finland, France, Germany, Hungary, Ireland, Israel, Italy, Netherlands, Norway, Poland, Portugal, Russia, Spain, Sweden, Switzerland, UK.

${ }^{6}$ Financial services and insurance companies are excluded due to special attributes of the financial industry.

${ }^{7}$ For the purposes of this study, we accessed RepRisk reputational exposure data via Orbis. At the time of writing, Orbis provides RepRisk exposure data for the period 2015-2018.

${ }^{8}$ Acknowledging that the UK dominates our sample ( $34 \%$ of observations), we also estimate the baseline model after excluding the UK (see the robustness test detailed later). ${ }^{9}$ RepRisk ratings do not measure reputation but rather indicate a firm's ESG-related reputational risk, facilitating assessment relative to peers and tracking over time (for more details, see RepRisk's research scope at: www. reprisk.com).
} 


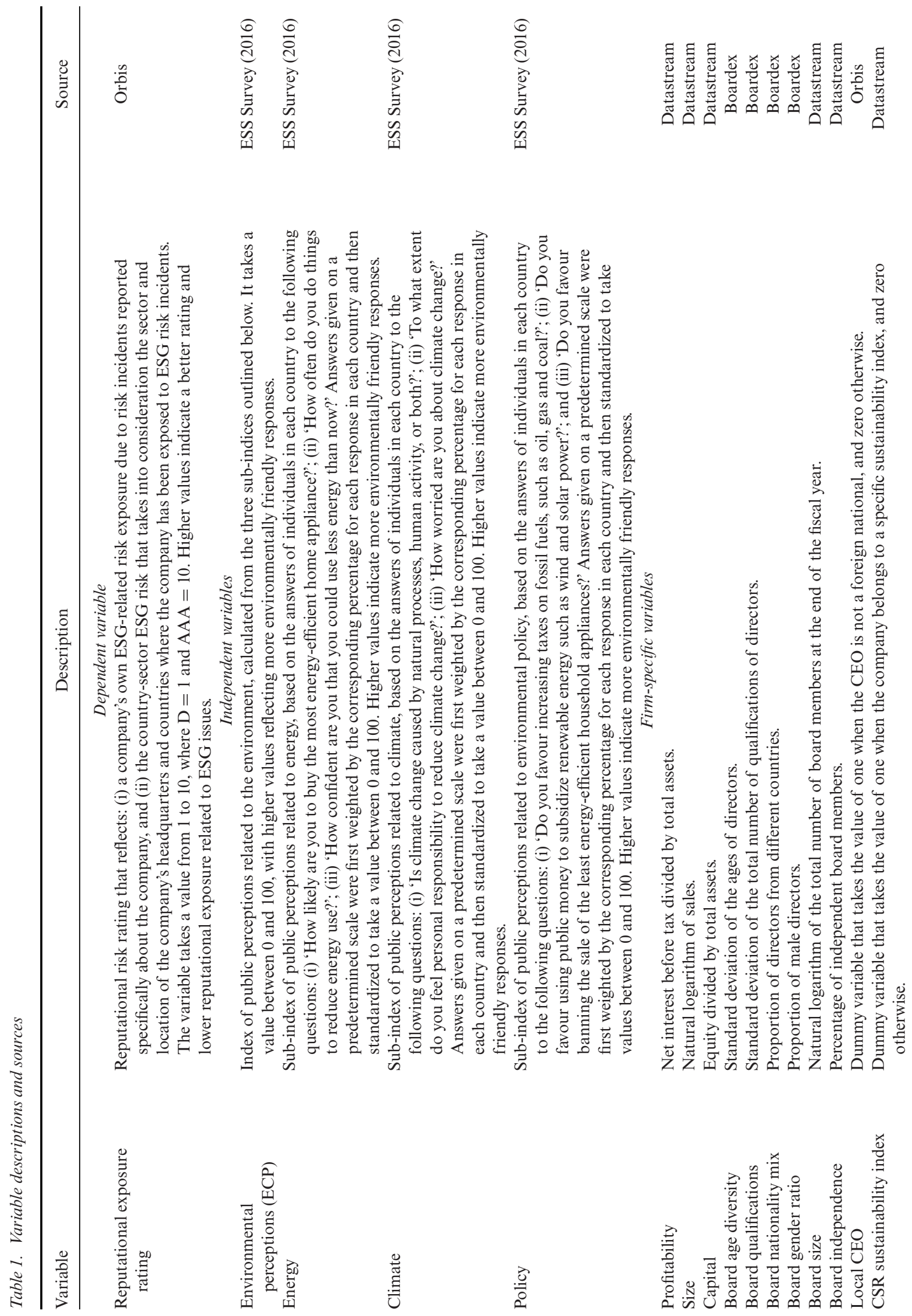




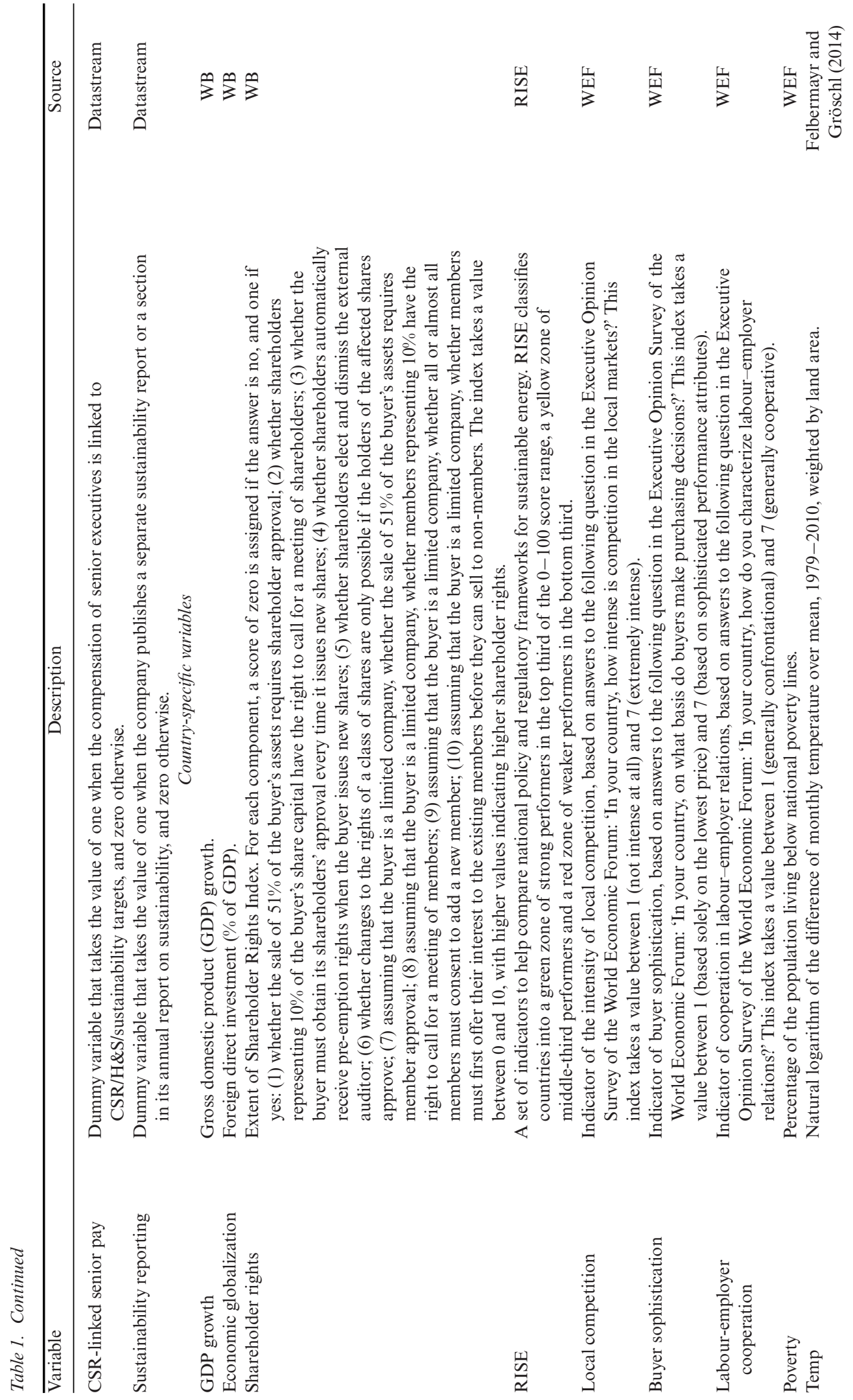




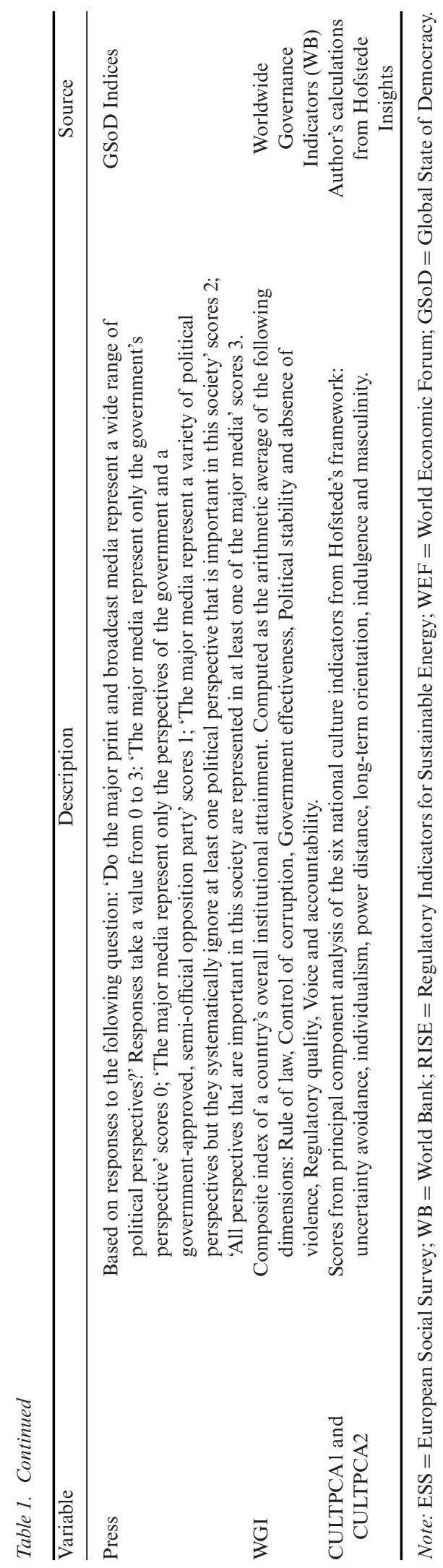

(C) 2021 The Authors. British Journal of Management published by John Wiley \& Sons Ltd on behalf of British Academy of Management. 
Table 2. Firm observations per country (2015-2018)

\begin{tabular}{lccc}
\hline Country & Frequency & Cum. \% \\
& & $\begin{array}{c}\text { Percentage } \\
(\%)\end{array}$ & 1.56 \\
\hline Austria & 10 & 1.56 & 4.04 \\
Belgium & 16 & 2.49 & 4.51 \\
Czech Republic & 3 & 0.47 & 8.24 \\
Finland & 24 & 3.73 & 20.37 \\
France & 78 & 12.13 & 29.55 \\
Germany & 59 & 9.18 & 29.7 \\
Hungary & 1 & 0.16 & 30.95 \\
Ireland & 8 & 1.24 & 32.35 \\
Israel & 9 & 1.4 & 35.93 \\
Italy & 23 & 3.58 & 39.66 \\
Netherlands & 24 & 3.73 & 41.99 \\
Norway & 15 & 2.33 & 44.48 \\
Poland & 16 & 2.49 & 45.72 \\
Portugal & 8 & 1.24 & 49.92 \\
Russia & 27 & 4.2 & 54.43 \\
Spain & 29 & 4.51 & 59.1 \\
Sweden & 30 & 4.67 & 7 \\
Switzerland & 45 & 33.9 & 100 \\
UK & 218 & $\mathbf{1 0 0}$ & \\
Total & $\mathbf{6 4 3}$ & & \\
\hline
\end{tabular}

necessarily focus on a set list of firms, thus assuring some impartiality. The 28 ESG issues drive the entire research process, and every risk incident in RepRisk's ESG risk platform is linked to at least one of these issues.

Incident categorizations map to the 10 principles of the United Nations Global Compact, and are related to: (i) environmental footprint (e.g. global pollution, overuse and wasting of resources); (ii) community relations (e.g. human rights abuses); (iii) employee relations (e.g. child labour); (iv) corporate governance (e.g. corruption, executive compensation issues); and (v) crosscutting issues (e.g. controversial products and services). The index also covers 50 ESG 'hot topics', such as palm oil, land mines, deep sea drilling and water scarcity. ${ }^{10}$ Each incident is also assigned two proprietary scores based on severity (the magni-

\footnotetext{
${ }^{10}$ The 'hot topics' are a dynamic concept, with the list expanding over time in line with developments and client feedback. The list included: Abusive/illegal fishing; Agricultural commodity speculation; Alcohol; Animal transportation; Arctic drilling; Asbestos; Automatic and semi-automatic weapons; Biological weapons; Chemical weapons; Cluster munitions; Coal-fired power plants; Conflict minerals; Coral reefs; Cyberattack; Deep sea drilling; Depleted uranium munitions; Diamonds; Drones; Endangered species; Forest burning; Fracking;
}

tude of the perceived impact) and reach (the influence or readership of source documents). The data only measure negative ESG impacts, and not positive ESG-related events. Although we would ideally consider both positive and negative reported impacts, positive events are less likely to be reported by the media and are mostly self-reported for marketing purposes, making it especially difficult to capture and quantify such data.

The RepRisk rating assigned to each company ranges from AAA (high quality/low risk) to D (low quality/high risk), similar to a credit rating. This rating reflects: (i) a company's own ESGrelated risk exposure due to risk incidents reported specifically about the company, and (ii) the

Fur and exotic animal skins; Gambling; Gender inequality; Genetically modified organisms; Genocide/Ethnic cleansing; High conservation value forests; Human trafficking; Hydropower (dams); Illegal logging; Indigenous people; Involuntary resettlement; Land grabbing; Land mines; Marijuana/Cannabis; Migrant labour; Monocultures; Mountaintop removal mining; Negligence; Nuclear power; Nuclear weapons; Offshore drilling; Oil sands; Palm oil; Pornography; Predatory lending; Privacy violations; Protected areas; Rare earths; Sand mining/dredging; Security services; Sea-bed mining; Ship breaking and scrapping; Soy; Tax havens; Tobacco; Water security. 


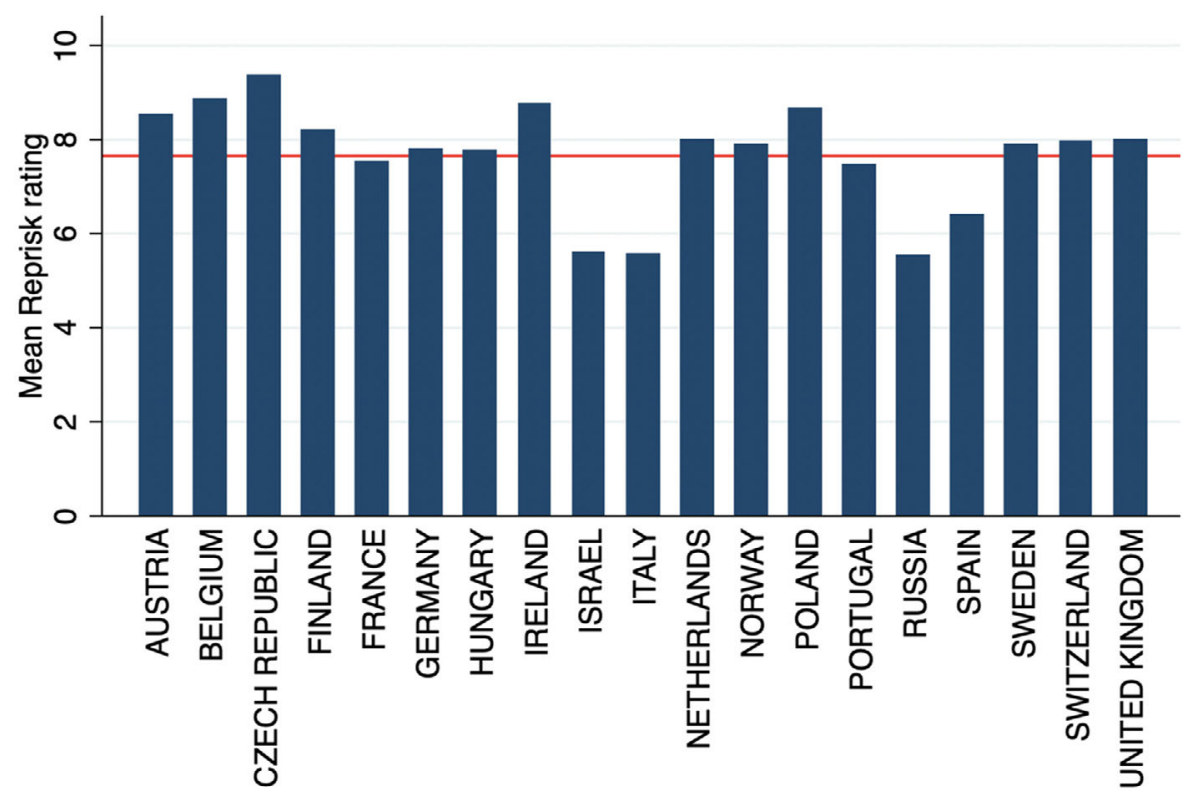

Figure 2. National mean values of RepRisk rating [Colour figure can be viewed at wileyonlinelibrary.com]

country-sector ESG risk, which considers the company's sector, the location of its headquarters and any countries where the company has been exposed to ESG risk incidents. Given its ordered nature, we follow the credit rating literature (see e.g. Ashbaugh-Skaife, Collins and LaFond, 2006) by converting the RepRisk ratings into a 10-point numeric scale in which higher numbers indicate higher quality and lower reputational exposure: $\mathrm{D} / \mathrm{C}=1, \mathrm{C}=2, \mathrm{CC}=3, \mathrm{CCC}=4, \mathrm{~B}=5, \mathrm{BB}$ $=6, \mathrm{BBB}=7, \mathrm{~A}=8, \mathrm{AA}=9, \mathrm{AAA}=10$. Figure 2 shows the national mean values of the dependent variable. The score ranges from 5.52 (Russia) to 9.36 (Czech Republic), with an overall sample mean of 7.65. Thus, there appears to be variation in reputational risk ratings across countries.

Key independent variables. The core variables of interest in our study are the measures of public attitudes on environmental issues. The ESS applies several methodological standards regarding questionnaire design, interview process, translation and data collection. The questionnaire design is developed every 2 years in English, including extensive testing and piloting by national teams (European Social Survey, 2016). Each country needs to achieve a minimum effective sample, representative of the country's population. The national coordinator, the sampling expert and possibly a representative of the survey agency col- lectively devise the optimum sampling design per country. Interviews are conducted face-to-face with individuals aged 15 and over (no upper age limit) residing in private households in each country, regardless of their nationality, citizenship or language. The full questionnaire and the complete ESS Round 8 dataset can be downloaded from http://www.europeansocialsurvey.org.

To construct our variables, we focus on answers to questions that elicit a person's beliefs regarding energy, climate and policy issues. We then use these three sub-indices to create an overall index of Environmental perceptions (also termed ECP). The Energy sub-index is based on answers to the following three questions: (i) 'How likely are you to buy the most energy-efficient home appliance?'; (ii) 'How often do you do things to reduce energy use?'; and (iii) 'How confident are you that you could use less energy than now?' To construct this sub-index, we weight answers on the predetermined response scale by the corresponding percentage for each response in each country. For example, question (i) above was answered on an 11-point scale ranging from 0 ('Not at all likely') to 10 ('Extremely likely'), and we weight these initial values with the corresponding percentages in each country. ${ }^{11}$ We follow a similar approach for each of the three questions,

\footnotetext{
${ }^{11}$ For example, the responses to question (i) in Austria were are as follows: $1.2 \%(0$, Not at all likely), $0.2 \%(1)$,
} 


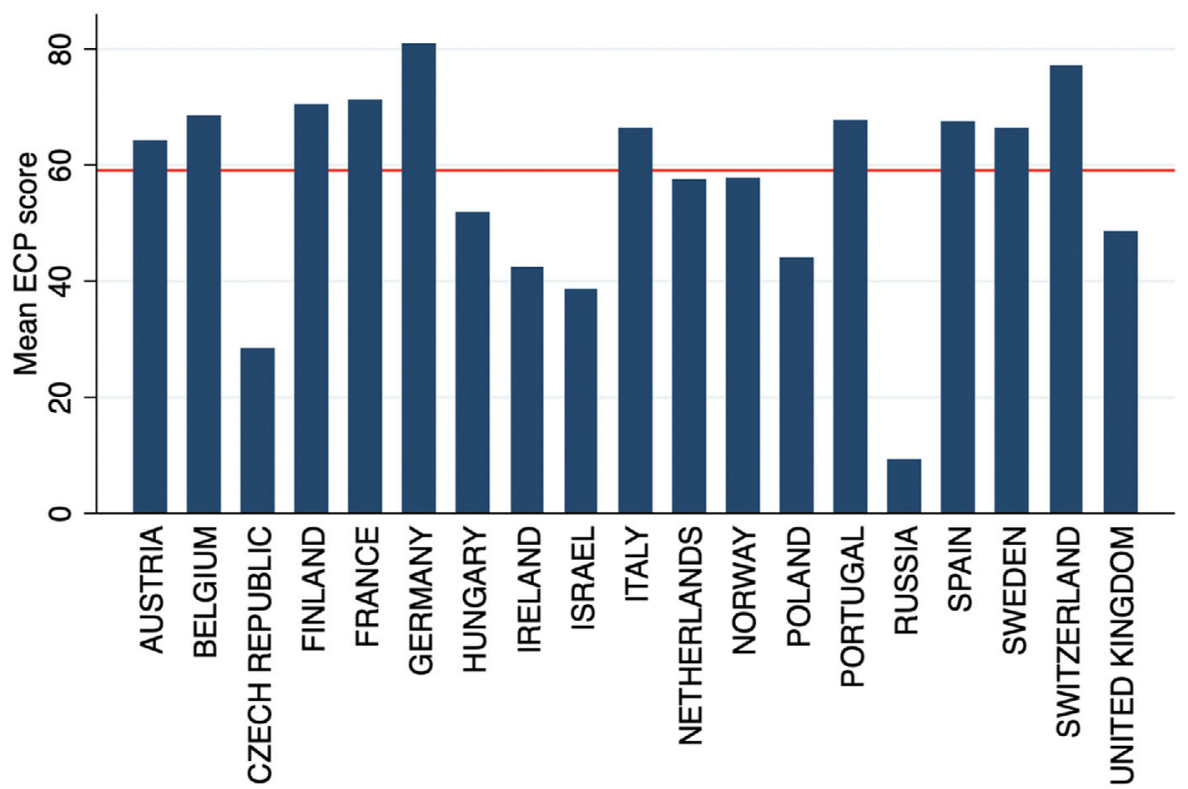

Figure 3. National mean values of ECP scores [Colour figure can be viewed at wileyonlinelibrary.com]

and then aggregate the three individual scores to construct the Energy sub-index. To achieve a consistent range of answers across questions and provide scores that are more meaningful, we rescale the values by applying $\min / \max$ normalization. In all cases, the sub-indices range between 0 (less environmentally friendly responses) and 100 (more environmentally friendly responses).

The Climate sub-index is based on the answers to the following questions: (i) 'Is climate change caused by natural processes, human activity, or both?'; (ii) 'To what extent do you feel personal responsibility to reduce climate change?'; and (iii) 'How worried are you about climate change?' Using the answers to these questions, the Climate subindex is calculated in the same way as the Energy sub-index. The Policy sub-index is calculated using the answers to three questions revealing the extent of public support for policies to reduce climate change: (i) 'Do you favour increasing taxes on fossil fuels, such as oil, gas and coal?'; (ii) 'Do you favour using public money to subsidize renewable energy such as wind and solar power?'; and (iii) 'Do you favour banning the sale of the least energy-efficient household appliances?' For all three questions, responses were given on a 5point scale: $1=$ 'strongly in favour', $2=$ 'somewhat in favour', $3=$ neither in favour nor against, $4=$ 'somewhat against', $5=$ 'strongly against'. We quantify and convert these responses in the same way as for the other two sub-indices, thereby creating a Policy sub-index ranging between 0 and 100 , with a higher score indicating stronger public support for adopting policies to reduce climate change.

Finally, we calculate the overall index, Environmental perceptions, as the average of the Energy, Climate and Policy sub-indices. ${ }^{12}$ Figure 3 shows the national mean values of our Environmental perceptions measure. We observe large differences across countries in the public Environmental perceptions of the public, with values ranging from a low of 9.15 in Russia to a high of 81.0 in Germany.

Control variables. Following earlier studies (Brammer and Pavelin, 2006; Deephouse, Newburry and Soleimani, 2016; Soleimani, Schneper and Newburry, 2014), we account for firm-specific financial and corporate governance attributes by controlling for: (i) Profitability (return on assets); (ii) Capital (equity to total assets); (iii) Size (natural logarithm of sales); (iv) Board size (natural

$0.9 \%(2), 1.2 \%(3), 1.6 \%(4), 6.8 \%(5), 6.9 \%(6), 14.8 \%$ (7), $19 \%(8), 15.5 \%(9), 31.9 \%$ (10, Extremely likely). Thus, the score for Austria is 801.5 , calculated as follows: $(1.2 \times 0)$ $+(0.2 \times 1)+(0.9 \times 2)+(1.2 \times 3)+(1.6 \times 4)+(6.8 \times 5)$ $+(6.9 \times 6)+(14.8 \times 7)+(19 \times 8)+(15.5 \times 9)+(31.9$ $\times 10)$. As a final step, we normalize the scores so that they range between 0 and 100 .

${ }^{12}$ The Appendix provides further details on the construction of these four variables. 
Table 3. Descriptive statistics (2015-2018)

\begin{tabular}{|c|c|c|c|c|c|}
\hline Variable & Obs. & Mean & Std Dev. & Min & Max \\
\hline Reputational exposure rating & 2372 & 7.640 & 2.089 & 1.000 & 10.000 \\
\hline Environmental perceptions & 2429 & 59.062 & 16.148 & 9.146 & 80.846 \\
\hline Energy & 2429 & 68.391 & 18.663 & 0.000 & 91.704 \\
\hline Climate & 2429 & 60.527 & 18.884 & 9.846 & 87.770 \\
\hline Policy & 2429 & 48.267 & 15.956 & 17.593 & 77.505 \\
\hline Profitability & 2429 & 0.063 & 0.051 & -0.015 & 0.154 \\
\hline Capital & 2429 & 0.404 & 0.165 & 0.158 & 0.671 \\
\hline Size & 2257 & 22.089 & 1.483 & 19.751 & 24.413 \\
\hline Local CEO & 1283 & 0.777 & 0.416 & 0.000 & 1.000 \\
\hline Board age diversity & 2193 & 7.517 & 2.304 & 0.000 & 19.500 \\
\hline Board qualifications & 1558 & 1.883 & 1.150 & 0.000 & 8.000 \\
\hline Board nationality mix & 2179 & 0.353 & 0.269 & 0.000 & 0.900 \\
\hline Board gender ratio & 2193 & 0.749 & 0.131 & 0.286 & 1.000 \\
\hline Board size & 1948 & 10.407 & 3.579 & 2.000 & 25.000 \\
\hline Board independence & 1944 & 46.614 & 28.372 & 0.000 & 100.000 \\
\hline CSR-linked senior pay & 2340 & 0.162 & 0.369 & 0.000 & 1.000 \\
\hline CSR sustainability index & 2344 & 0.506 & 0.500 & 0.000 & 1.000 \\
\hline Sustainability reporting & 2344 & 0.904 & 0.295 & 0.000 & 1.000 \\
\hline GDP growth & 2429 & 2.022 & 1.718 & -2.828 & 25.557 \\
\hline Economic globalization & 2429 & -0.005 & 0.048 & -0.160 & 0.170 \\
\hline Shareholder rights & 2429 & 6.718 & 1.037 & 4.000 & 9.000 \\
\hline RISE & 2429 & 86.552 & 6.591 & 64.850 & 93.700 \\
\hline Local competition & 2429 & 5.630 & 0.344 & 4.200 & 6.021 \\
\hline Buyer sophistication & 2406 & 4.366 & 0.493 & 2.553 & 5.100 \\
\hline $\begin{array}{l}\text { Labour-employment } \\
\text { cooperation }\end{array}$ & 2406 & 5.022 & 0.705 & 3.606 & 6.200 \\
\hline Poverty & 1639 & 0.230 & 0.376 & 0.000 & 2.000 \\
\hline Temp & 2389 & -6.139 & 1.646 & -8.732 & -3.280 \\
\hline Press & 2418 & 0.798 & 0.104 & 0.340 & 0.890 \\
\hline WGI & 2429 & 1.275 & 0.526 & -0.760 & 1.820 \\
\hline CULTPCA1 & 2395 & 8.66e-09 & 1.837315 & -1.914008 & 4.82435 \\
\hline CULTPCA2 & 2395 & $9.61 \mathrm{e}-09$ & 1.115899 & -2.659399 & 1.672378 \\
\hline
\end{tabular}

Note: All financial variables are winsorized at the 10 th and 90 th percentiles.

logarithm of number of directors); (v) Board independence (percentage of independent board members); and (vi) CSR-linked senior pay (executive compensation related to $\mathrm{CSR} / \mathrm{H} \& \mathrm{~S} /$ Sustainability targets). ${ }^{13}$

Finally, we include several country-level variables to account for potential forms of heterogeneity across countries that may influence corporate reputation. Specifically, we control for: (i) GDP growth (\%); (ii) Economic globalization (FDI/GDP, $\%$ ); (iii) Shareholder rights (WB's Extent of Shareholders Rights Index); and (iv) RISE (national regulations for sustainable energy). Later, we consider additional country-specific control variables to account for: (i) Buyer sophistication; (ii) Local competition (intensity); (iii) Labour-employer cooperation; and (iv) Poverty. Research has also shown that industry reputation may influence the perception of individual companies (Soleimani, Schneper and Newburry, 2014; Winn, MacDonald and Ziestsma, 2008). Therefore, we control for industry effects using dummy variables.

Table 3 reports descriptive statistics for the dependent and independent variables. We winsorize all variables at the 10 th and 90 th percentiles to minimize the potential impact of outliers. The correlation matrices for all variables are reported in Tables $4 \mathrm{a}$ and $4 \mathrm{~b}$. Although there are a few moderately high correlations among country-level controls (between 0.32 and 0.57), the only correlation above 0.7 is between Labour-employer

\footnotetext{
${ }^{13}$ In further analysis below, we consider additional corporate social responsibility (CSR) measures.
} 


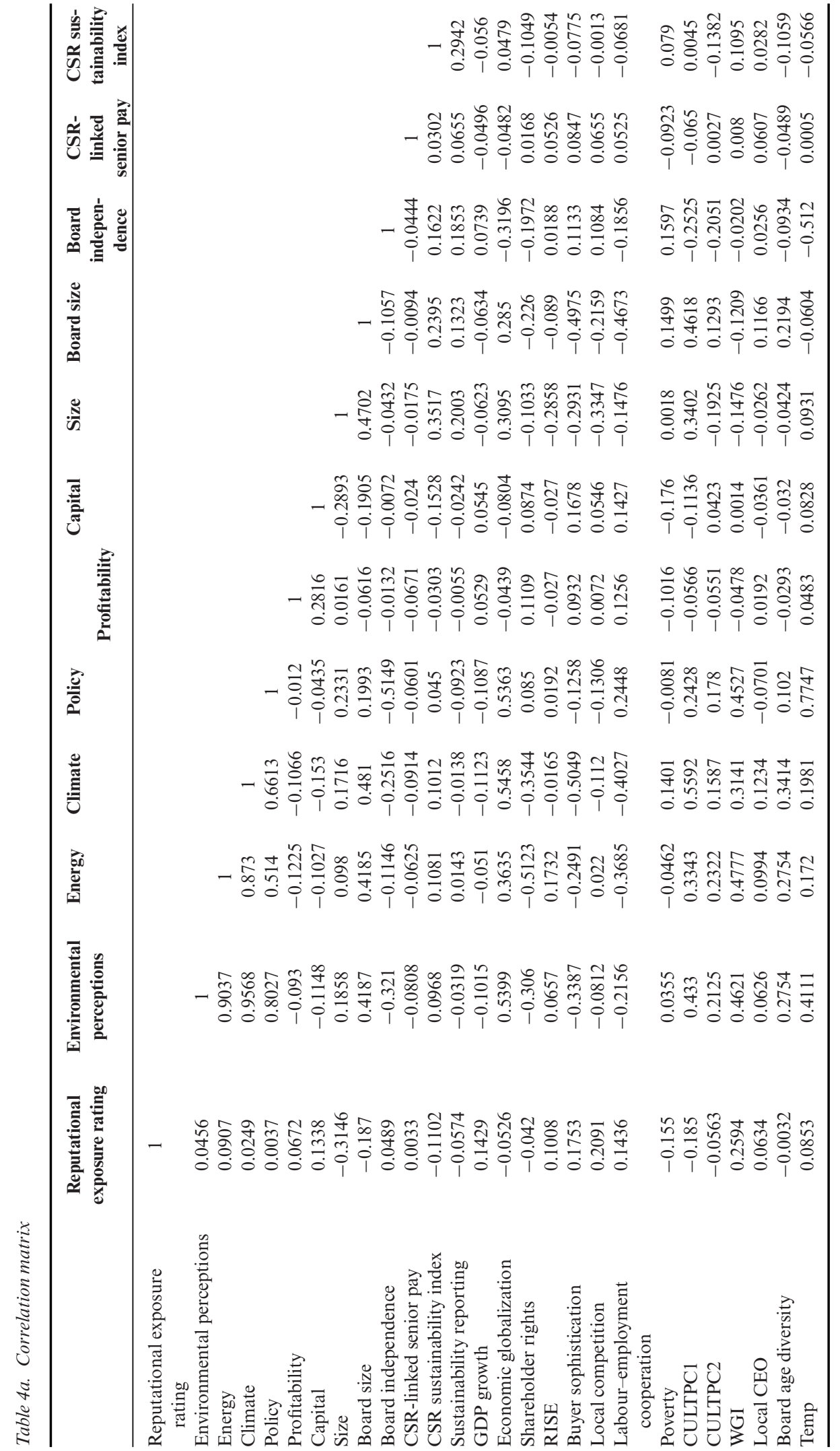




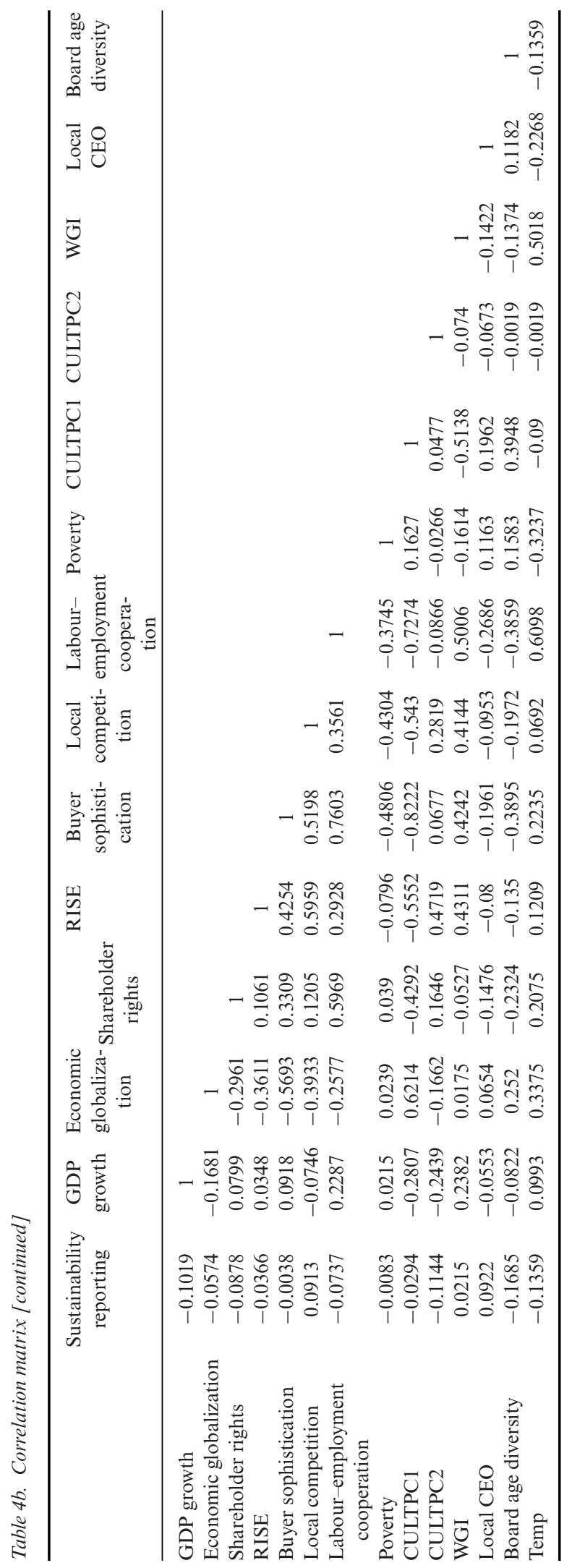


cooperation and Buyer sophistication. Regarding the core variables of interest, we observe that the perceptions variables are positively associated with the RepRisk ratings, providing some preliminary evidence that public attitudes on environmental issues are associated with lower reputational exposure.

\section{Estimation method}

To examine how public perceptions on environmental issues impact on reputational risk, we derive a model that represents reputational exposure rating as a function of perception, firmand country-specific characteristics. In its general form, the model is as follows:

$$
\begin{aligned}
& \text { Reputational exposure rating } \\
& =\mathrm{f}\left(\text { Perception, Firm } \text { speci } \| c_{c}, \text { Country }_{\text {Speci } \| c}\right. \\
& \quad \text { variables })
\end{aligned}
$$

where Reputational exposure rating refers to the reputational risk rating of an individual firm (as discussed above); Perception represents the index ECP or one of the three sub-indices; and Firm $_{\text {specific }}$ and Country specific $_{\text {represent the cor- }}$ responding control variables. Time and industry dummies are also included in our model. We use an ordered probit model due to the ordinal nature of our categorical dependent variable. Our approach is consistent with that used in the credit ratings literature (see e.g. Khatami, Marchica and Mura, 2016; Papadimitri et al., 2020).

\section{Empirical results}

\section{Ordered probit results for $\mathrm{HI}$}

Table 5 shows the results of the baseline model. In column 1, we investigate the impact of Environmental perceptions while controlling for basic firm, country- and industry-level factors. In the next columns we present the results for the sub-indices of Energy (column 2), Climate (column 3) and Policy (column 4).

Environmental perceptions appear to have a significantly positive impact on Reputational exposure rating (at the $1 \%$ level), and this finding holds when we decompose the overall index into the three sub-indices. Overall, our results show that in countries where the public demonstrates more environmentally friendly attitudes and beliefs, com- panies are more likely to have better reputational risk ratings, and hence lower reputational exposure, providing support for H1a. One potential explanation is that, consistent with systems theory, these firms' managers carefully analyse the operating environment, including public perceptions, and adapt their practices accordingly (Logsdon and Yuthas, 1997). Therefore, this pressure from the public incentivizes firms to advance their frontier in relation to ESG issues, eventually meeting the expectations of stakeholders and lowering their reputational exposure.

\section{Ordered probit results for $\mathrm{H} 2$}

Up to this point, we have used energy, climate and the adoption of relevant policies to highlight public perceptions of environment-related issues. Such beliefs may play the role of informal institutions, since firms may be subject to different levels of institutional pressures. However, as discussed, recent research suggests that a company's ability to interpret the public perceptions that drive social institutional pressures, and react accordingly, depends on certain board characteristics.

For instance, foreign chief executive officers (CEOs) may perceive and interpret public pressures differently from local CEOs if they come from a society that does not share the same public aspirations. Consequently, external institutional pressures and CEO nationality may interact to affect corporate reputational exposure. To account for this, we introduce the dummy variable Local $C E O$ that takes the value of one for a local CEO and zero for a foreign CEO, and we interact it with the indicators of public perceptions. We present the results in Table 6 . In general, the interaction term is insignificant, failing to provide support for $\mathrm{H} 2$.

In addition, based on previous studies on top management teams, we examine the influence of different kinds of board demographics such as age, qualifications, nationality mix and gender. The reasoning is in line with upper echelons theory, which states that organizational outcomes related to strategic choices and performance are partially predicted by the background characteristics of top executives (see e.g. Bromiley and Rau, 2015; Carpenter, Geletkanycz and Sanders, 2004; Hambrick and Mason, 1984). More specifically, Hambrick and Mason (1984) assert that observable characteristics of top managers, such as their age, 
Table 5. Baseline results

\begin{tabular}{|c|c|c|c|c|}
\hline Variable & (1) & (2) & (3) & (4) \\
\hline Environmental perceptions & $\begin{array}{c}0.00878^{* * *} \\
(0.00181)\end{array}$ & & & \\
\hline Energy & & $\begin{array}{c}0.00813^{* * *} \\
(0.00174)\end{array}$ & & \\
\hline Climate & & & $\begin{array}{c}0.00578 * * * \\
(0.00173)\end{array}$ & \\
\hline Policy & & & & $\begin{array}{c}0.00835^{* * * *} \\
(0.00168)\end{array}$ \\
\hline Profitability & $\begin{array}{c}0.464 \\
(0.488)\end{array}$ & $\begin{array}{c}0.477 \\
(0.489)\end{array}$ & $\begin{array}{c}0.373 \\
(0.487)\end{array}$ & $\begin{array}{c}0.458 \\
(0.488)\end{array}$ \\
\hline Capital & $\begin{array}{c}0.182 \\
(0.164)\end{array}$ & $\begin{array}{c}0.168 \\
(0.164)\end{array}$ & $\begin{array}{c}0.196 \\
(0.164)\end{array}$ & $\begin{array}{c}0.173 \\
(0.164)\end{array}$ \\
\hline Size & $\begin{array}{c}-0.0931 * * * \\
(0.0212)\end{array}$ & $\begin{array}{c}-0.0893^{* * *} \\
(0.0212)\end{array}$ & $\begin{array}{c}-0.0871 * * * \\
(0.0212)\end{array}$ & $\begin{array}{c}-0.108 * * * \\
(0.0213)\end{array}$ \\
\hline Board size & $\begin{array}{c}-0.0480 * * * \\
(0.00846)\end{array}$ & $\begin{array}{c}-0.0487 * * * \\
(0.00854)\end{array}$ & $\begin{array}{c}-0.0500^{* * *} \\
(0.00870)\end{array}$ & $\begin{array}{c}-0.0394 * * * \\
(0.00846)\end{array}$ \\
\hline Board independence & $\begin{array}{c}0.000499 \\
(0.000912)\end{array}$ & $\begin{array}{c}0.000370 \\
(0.000908)\end{array}$ & $\begin{array}{c}0.000236 \\
(0.000905)\end{array}$ & $\begin{array}{c}0.000745 \\
(0.000917)\end{array}$ \\
\hline CSR-linked senior pay & $\begin{array}{l}-0.0498 \\
(0.0655)\end{array}$ & $\begin{array}{l}-0.0535 \\
(0.0657)\end{array}$ & $\begin{array}{l}-0.0540 \\
(0.0655)\end{array}$ & $\begin{array}{l}-0.0527 \\
(0.0654)\end{array}$ \\
\hline GDP growth & $\begin{array}{c}0.0397 * * * \\
(0.00979)\end{array}$ & $\begin{array}{c}0.0362 * * * \\
(0.00964)\end{array}$ & $\begin{array}{c}0.0409 * * * \\
(0.00994)\end{array}$ & $\begin{array}{c}0.0417 * * * \\
(0.00991)\end{array}$ \\
\hline Economic globalization & $\begin{array}{c}0.915 \\
(0.566)\end{array}$ & $\begin{array}{l}1.210^{* *} \\
(0.550)\end{array}$ & $\begin{array}{l}1.219^{* *} \\
(0.564)\end{array}$ & $\begin{array}{c}0.777 \\
(0.579)\end{array}$ \\
\hline Shareholder rights & $\begin{array}{c}-0.107 * * * \\
(0.0278)\end{array}$ & $\begin{array}{c}-0.0740^{* *} \\
(0.0312)\end{array}$ & $\begin{array}{c}-0.111 * * * \\
(0.0283)\end{array}$ & $\begin{array}{c}-0.151^{* * *} \\
(0.0267)\end{array}$ \\
\hline RISE & $\begin{array}{l}-0.00105 \\
(0.00459)\end{array}$ & $\begin{array}{l}-0.00330 \\
(0.00485)\end{array}$ & $\begin{array}{c}0.00168 \\
(0.00455)\end{array}$ & $\begin{array}{c}0.00157 \\
(0.00435)\end{array}$ \\
\hline Observations & 2,025 & 2,025 & 2,025 & 2,025 \\
\hline Industry dummies & YES & YES & YES & YES \\
\hline Time dummies & YES & YES & YES & YES \\
\hline R-sq. & 0.0320 & 0.0318 & 0.0309 & 0.0322 \\
\hline
\end{tabular}

Notes: Ordered probit results from Eq. (1). Column 1 reports results for the 'Baseline' model when the key independent variable is the overall ECP measure. Columns 2-4 report results when the overall ECP measure is decomposed into the Environmental, Climate and Policy sub-indices, respectively. All financial variables are winsorized at the 10th and 90th percentiles. The variables are defined in Table 1. Robust standard errors are reported in parentheses.

$* * * \mathrm{p}<0.01$

$* * \mathrm{p}<0.05$.

education, experience and socioeconomic roots, serve as proxies of their cognitions, values and perspectives, and more generally for psychological dimensions that are difficult to observe and measure. To test these effects, we condition the environmental perception variables on Board age diversity, Board qualifications, Board nationality mix and Board gender ratio. ${ }^{14}$

\footnotetext{
${ }^{14}$ In general, empirical literature on upper echelons theory focuses on attributes like education, age and experience as observable characteristics that could proxy for unobservable ones. However, as discussed by Carpenter, Geletkanycz and Sanders (2004), studies have considered managerial characteristics not necessarily mentioned in
}

The results in Table 7 partially support upper echelons theory, with a significantly positive coefficient on the interaction term of Board age diversity with Environmental perceptions, Climate and Policy. Consistent with $\mathrm{H} 2$, these findings imply that external institutional pressures and the age diversity of board members may interact to affect corporate reputational exposure. This finding might be explained by the wider range of ideas and perceptions among directors who differ in age, which proves helpful when a firm struggles to find

the seminal work of Hambrick and Mason (1984), such as race and gender diversity (Richard et al., 2004). This is why we also consider such attributes in our analysis. 
Table 6. CEO nationality

\begin{tabular}{|c|c|c|c|c|}
\hline Variable & (1) & (2) & (3) & (4) \\
\hline Environmental perceptions & $\begin{array}{c}0.00355 \\
(0.00626)\end{array}$ & & & \\
\hline Local CEO & $\begin{array}{l}-0.488 \\
(0.409)\end{array}$ & $\begin{array}{l}-0.735 \\
(0.584)\end{array}$ & $\begin{array}{l}-0.264 \\
(0.374)\end{array}$ & $\begin{array}{l}-0.308 \\
(0.284)\end{array}$ \\
\hline $\begin{array}{l}\text { Environmental } \times \text { Local } \\
\quad \text { CEO }\end{array}$ & $\begin{array}{c}0.00945 \\
(0.00664)\end{array}$ & & & \\
\hline Energy & & $\begin{array}{c}-0.000453 \\
(0.00783)\end{array}$ & & \\
\hline Energy $\times$ Local CEO & & $\begin{array}{c}0.0117 \\
(0.00826)\end{array}$ & & \\
\hline Climate & & & $\begin{array}{c}0.00312 \\
(0.00573)\end{array}$ & \\
\hline Climate $\times$ Local CEO & & & $\begin{array}{c}0.00538 \\
(0.00601)\end{array}$ & \\
\hline Policy & & & & $\begin{array}{c}0.00436 \\
(0.00522)\end{array}$ \\
\hline Policy $\times$ Local CEO & & & & $\begin{array}{c}0.00813 \\
(0.00541)\end{array}$ \\
\hline Profitability & $\begin{array}{c}0.593 \\
(0.744)\end{array}$ & $\begin{array}{c}0.512 \\
(0.745)\end{array}$ & $\begin{array}{c}0.491 \\
(0.741)\end{array}$ & $\begin{array}{c}0.639 \\
(0.749)\end{array}$ \\
\hline Capital & $\begin{array}{c}0.258 \\
(0.245)\end{array}$ & $\begin{array}{c}0.263 \\
(0.245)\end{array}$ & $\begin{array}{c}0.282 \\
(0.245)\end{array}$ & $\begin{array}{c}0.213 \\
(0.246)\end{array}$ \\
\hline Size & $\begin{array}{l}-0.148 * * * \\
(0.0323)\end{array}$ & $\begin{array}{c}-0.141 * * * \\
(0.0326)\end{array}$ & $\begin{array}{c}-0.140 * * * \\
(0.0325)\end{array}$ & $\begin{array}{c}-0.169^{* * * *} \\
(0.0327)\end{array}$ \\
\hline Board size & $\begin{array}{c}-0.0343^{* * *} \\
(0.0121)\end{array}$ & $\begin{array}{c}-0.0351^{* * *} \\
(0.0124)\end{array}$ & $\begin{array}{c}-0.0341 * * * \\
(0.0126)\end{array}$ & $\begin{array}{c}-0.0232^{* *} \\
(0.0116)\end{array}$ \\
\hline Board independence & $\begin{array}{c}0.00187 \\
(0.00155)\end{array}$ & $\begin{array}{c}0.00133 \\
(0.00153)\end{array}$ & $\begin{array}{c}0.00145 \\
(0.00152)\end{array}$ & $\begin{array}{c}0.00246 \\
(0.00157)\end{array}$ \\
\hline CSR-linked senior pay & $\begin{array}{c}0.0121 \\
(0.0981)\end{array}$ & $\begin{array}{l}0.00108 \\
(0.0981)\end{array}$ & $\begin{array}{l}0.00786 \\
(0.0980)\end{array}$ & $\begin{array}{l}0.00917 \\
(0.0979)\end{array}$ \\
\hline GDP growth & $\begin{array}{c}0.0724 * * * \\
(0.0255)\end{array}$ & $\begin{array}{c}0.0715^{* * * *} \\
(0.0256)\end{array}$ & $\begin{array}{c}0.0753 * * * \\
(0.0264)\end{array}$ & $\begin{array}{c}0.0737 * * * \\
(0.0257)\end{array}$ \\
\hline Economic globalization & $\begin{array}{c}0.995 \\
(0.982)\end{array}$ & $\begin{array}{c}1.480 \\
(0.956)\end{array}$ & $\begin{array}{c}1.262 \\
(0.975)\end{array}$ & $\begin{array}{c}0.807 \\
(1.004)\end{array}$ \\
\hline Shareholder rights & $\begin{array}{l}-0.0215 \\
(0.0474)\end{array}$ & $\begin{array}{c}0.0199 \\
(0.0553)\end{array}$ & $\begin{array}{l}-0.0338 \\
(0.0478)\end{array}$ & $\begin{array}{c}-0.0857^{* *} \\
(0.0437)\end{array}$ \\
\hline RISE & $\begin{array}{l}0.000888 \\
(0.00878)\end{array}$ & $\begin{array}{l}-0.00174 \\
(0.00939)\end{array}$ & $\begin{array}{c}0.00634 \\
(0.00844)\end{array}$ & $\begin{array}{c}0.00251 \\
(0.00836)\end{array}$ \\
\hline Observations & 908 & 908 & 908 & 908 \\
\hline Industry dummies & YES & YES & YES & YES \\
\hline Time dummies & YES & YES & YES & YES \\
\hline R-sq. & 0.0350 & 0.0345 & 0.0336 & 0.0352 \\
\hline
\end{tabular}

Notes: Ordered probit results from Eq. (1) when including CEO nationality as a moderator variable. Column 1 reports results when the key independent variable is the overall ECP measure. Columns 2-4 report results when the overall ECP measure is decomposed into the Environmental, Climate and Policy sub-indices, respectively. All financial variables are winsorized at the 10th and 90th percentiles. The variables are defined in Table 1. Robust standard errors are reported in parentheses.

*** $\mathrm{p}<0.01$.

$* * \mathrm{p}<0.05$.

solutions for compliance issues (Kumar, 2020), subsequently resulting in lower reputational exposure. This should not be surprising as studies have suggested since at least the late 1970s (e.g. Buttel, 1979) that age is closely and consistently related to attitudinal indicators of environmental concerns. ${ }^{15}$ Most importantly, the literature suggests

${ }^{15}$ Honnold (1984) outlines two main explanations for the inverse relationship between age and environmental 
Table 7. Board age diversity

\begin{tabular}{|c|c|c|c|c|}
\hline Variable & (1) & (2) & (3) & (4) \\
\hline Environmental perceptions & $\begin{array}{l}-0.00497 \\
(0.00593)\end{array}$ & & & \\
\hline Board age diversity & $\begin{array}{c}-0.114^{* *} \\
(0.0465)\end{array}$ & $\begin{array}{l}-0.0650 \\
(0.0447)\end{array}$ & $\begin{array}{c}-0.0913^{* *} \\
(0.0401)\end{array}$ & $\begin{array}{c}-0.117 * * * \\
(0.0370)\end{array}$ \\
\hline Environmental $\times$ Age & $\begin{array}{l}0.00164 * * \\
(0.000738)\end{array}$ & & & \\
\hline Energy & & $\begin{array}{c}0.00205 \\
(0.00527)\end{array}$ & & \\
\hline Energy $\times$ Age & & $\begin{array}{c}0.000726 \\
(0.000618)\end{array}$ & & \\
\hline Climate & & & $\begin{array}{l}-0.00525 \\
(0.00521)\end{array}$ & \\
\hline Climate $\times$ Age & & & $\begin{array}{l}0.00120^{*} \\
(0.000618)\end{array}$ & \\
\hline Policy & & & & $\begin{array}{l}-0.00798 \\
(0.00549)\end{array}$ \\
\hline Policy $\times$ Age & & & & $\begin{array}{c}0.00213 * * * \\
(0.000710)\end{array}$ \\
\hline Profitability & $\begin{array}{c}0.481 \\
(0.568)\end{array}$ & $\begin{array}{c}0.504 \\
(0.568)\end{array}$ & $\begin{array}{c}0.391 \\
(0.567)\end{array}$ & $\begin{array}{c}0.513 \\
(0.570)\end{array}$ \\
\hline Capital & $\begin{array}{c}0.177 \\
(0.191)\end{array}$ & $\begin{array}{c}0.154 \\
(0.191)\end{array}$ & $\begin{array}{c}0.175 \\
(0.191)\end{array}$ & $\begin{array}{c}0.175 \\
(0.192)\end{array}$ \\
\hline Size & $\begin{array}{c}-0.113 * * * \\
(0.0247)\end{array}$ & $\begin{array}{c}-0.111 * * * \\
(0.0248)\end{array}$ & $\begin{array}{c}-0.111^{* * *} \\
(0.0248)\end{array}$ & $\begin{array}{c}-0.128^{* * *} \\
(0.0245)\end{array}$ \\
\hline Board size & $\begin{array}{c}-0.0493 * * * \\
(0.0103)\end{array}$ & $\begin{array}{c}-0.0499 * * * \\
(0.0104)\end{array}$ & $\begin{array}{c}-0.0494^{* * *} \\
(0.0105)\end{array}$ & $\begin{array}{c}-0.0416^{* * *} \\
(0.0103)\end{array}$ \\
\hline Board independence & $\begin{array}{l}0.000180 \\
(0.00103)\end{array}$ & $\begin{array}{l}7.05 e-05 \\
(0.00103)\end{array}$ & $\begin{array}{c}-0.000102 \\
(0.00102)\end{array}$ & $\begin{array}{l}0.000479 \\
(0.00103)\end{array}$ \\
\hline CSR-linked senior pay & $\begin{array}{c}0.0319 \\
(0.0778)\end{array}$ & $\begin{array}{c}0.0292 \\
(0.0777)\end{array}$ & $\begin{array}{c}0.0266 \\
(0.0779)\end{array}$ & $\begin{array}{c}0.0318 \\
(0.0775)\end{array}$ \\
\hline GDP growth & $\begin{array}{c}0.0566^{* * *} \\
(0.0179)\end{array}$ & $\begin{array}{c}0.0535^{* * *} \\
(0.0180)\end{array}$ & $\begin{array}{c}0.0597 * * * \\
(0.0186)\end{array}$ & $\begin{array}{c}0.0592^{* * * *} \\
(0.0179)\end{array}$ \\
\hline Economic globalization & $\begin{array}{c}0.620 \\
(0.616)\end{array}$ & $\begin{array}{c}0.735 \\
(0.599)\end{array}$ & $\begin{array}{c}0.978 \\
(0.613)\end{array}$ & $\begin{array}{c}0.512 \\
(0.630)\end{array}$ \\
\hline Shareholder rights & $\begin{array}{c}-0.0996 * * * \\
(0.0331)\end{array}$ & $\begin{array}{c}-0.0693^{*} \\
(0.0369)\end{array}$ & $\begin{array}{c}-0.112 * * * \\
(0.0330)\end{array}$ & $\begin{array}{c}-0.143 * * * \\
(0.0315)\end{array}$ \\
\hline RISE & $\begin{array}{l}-0.00552 \\
(0.00528)\end{array}$ & $\begin{array}{r}-0.00734 \\
(0.00557)\end{array}$ & $\begin{array}{c}-0.00196 \\
(0.00517)\end{array}$ & $\begin{array}{l}-0.00428 \\
(0.00506)\end{array}$ \\
\hline Observations & 1,539 & 1,539 & 1,539 & 1,539 \\
\hline Industry dummies & YES & YES & YES & YES \\
\hline Time dummies & YES & YES & YES & YES \\
\hline R-sq. & 0.0324 & 0.0322 & 0.0310 & 0.0333 \\
\hline
\end{tabular}

Notes: Ordered probit results from Eq. (1) when including the standard deviation of the age of directors as a moderator variable. Column 1 reports results when the key independent variable is the overall ECP measure. Columns $2-4$ report results when the overall ECP measure is decomposed into the Environmental, Climate and Policy sub-indices, respectively. All financial variables are winsorized at the 10th and 90th percentiles. The variables are defined in Table 1. Robust standard errors are reported in parentheses.

$* * * \mathrm{p}<0.01$

$* * \mathrm{p}<0.05$.

$* \mathrm{p}<0.1$

that the age of the board of directors and the top management team influences environmental dis-

concerns: (i) the socio-biological process of aging; and (ii) important historical events differently affecting birth cohorts. closures (Fernandes, Bornia and Nakamura, 2019) and environmental compliance initiatives (Kumar, 2020). Finally, we find no evidence of a conditional effect from the remaining board demographics (results untabulated), and thus we fail to find further and strong support for upper echelons theory. 


\section{Additional analyses}

In this section, we present further analysis of: (i) alternative CSR measures; (ii) additional countrylevel attributes; (iii) altered samples; and (iv) endogeneity. We discuss these tests in turn.

Alternative CSR measures. Various studies point to a positive relationship between social performance and better reputation (Brammer and Pavelin, 2004, 2006). As discussed in Soleimani, Schneper and Newburry (2014), since reputation refers to public perceptions of the firm, CSR reporting and participation in voluntary initiatives are particularly relevant because they provide highly visible signals of commitment to CSR. Additionally, RepRisk mentions that its ratings take into account various allegations related to social issues. We therefore introduce two more CSRrelated variables. The first is a dummy variable, CSR sustainability index, that takes the value of one if the company belongs to a specific sustainability index, and zero otherwise. The second is a dummy variable, Sustainability reporting, that takes the value of one if the company publishes a separate sustainability report or a section in its annual report on sustainability, and zero otherwise. The results in Table 8 show that both CSR dummies enter our regressions with an insignificant coefficient; the main results do not change.

Additional country-related controls. We further account for several country-related factors that can influence reputational exposure. Using firmlevel data from the WEF database, Walsh et al. (2009) find that customer satisfaction and trust significantly impact on corporate reputation. In the absence of firm-level customer data, we control for buyer sophistication at the country level. This indicator reveals the extent to which buyers base their purchases on sophisticated performance attributes and not only on the lowest price. The results in Table 9 confirm the findings of previous studies in that Buyer sophistication significantly affects Reputational exposure ratings. The effect is positive and statistically significant at the $1 \%$ level (except in the model with Policy - column 4 - where it falls to $5 \%$ ).

Hörner (2002) built a theoretical model that shows how competition generates reputationbuilding behaviour. For example, having a competitor in the market may allow consumers to cred- ibly punish one firm's dishonest behaviour, thus raising the importance of building and maintaining reputation. We control for the impact of local competition on reputational exposure using an index of the intensity of competition in each country. We find that Local competition is positively associated with Reputational exposure ratings at the 1\% level (columns 5-8), and the environmental perception variables continue to have statistically significant coefficients at the $1 \%$ level. Additionally, we control for the extent of cooperation in labouremployer relations. Helm (2011) outlines the important role of employees in reputation building: 'employees can directly or indirectly, voluntarily or involuntarily, affect reputation by any act that is transmitted to, and communicated by, external audiences who evaluate corporate conduct' ( $\mathrm{p}$. 658). Miles and Mangold (2014) also highlight that in the era of the Internet and social media, the voice of employees can either enhance the organization's public image or be a ticking bomb with adverse effects on corporate reputation. We find that Labour-employer cooperation is associated with lower reputational exposure (statistically significant at the $1 \%$ level: columns 9-12). Additionally, we control for the impact of poverty using the percentage of the population living below national poverty lines (WEF). The World Economic Forum (2012) outlines that in most countries, improvements in economic living standards are being accompanied by increases in political and civil rights such as freedom of speech, assembly and beliefs. This might have further implications for the priorities, attitude and reactions of citizens in wealthy and less wealthy countries. For example, Lo (2016) finds that the citizens of wealthier societies are more strongly motivated to take environmental action than the citizens of lower-income countries, although at the same time they are relatively less likely to perceive the harmful impacts on the environment as very dangerous. Therefore, the expectations of the citizens and the corporate reactions may differ by level of income, with implications for organizational fit and subsequently corporate reputational exposure. The results in Table 10 reveal a negative relationship between Poverty and Reputational exposure ratings, implying that in countries with a high percentage of poverty, companies' reputational exposure is also higher. The main results hold.

Given that the Reputational exposure ratings indicator captures negative incidents, criticism and 
Table 8. Additional CSR variables

\begin{tabular}{|c|c|c|c|c|}
\hline Variable & (1) & (2) & (3) & (4) \\
\hline Environmental perceptions & $\begin{array}{c}0.00902^{* * *} \\
(0.00194)\end{array}$ & & & \\
\hline Energy & & $\begin{array}{c}0.00885^{* * *} \\
(0.00191)\end{array}$ & & \\
\hline Climate & & & $\begin{array}{c}0.00578^{* * *} * \\
(0.00186)\end{array}$ & \\
\hline Policy & & & & $\begin{array}{c}0.00863 * * * \\
(0.00181)\end{array}$ \\
\hline Profitability & $\begin{array}{c}0.560 \\
(0.529)\end{array}$ & $\begin{array}{c}0.570 \\
(0.530)\end{array}$ & $\begin{array}{c}0.467 \\
(0.528)\end{array}$ & $\begin{array}{c}0.575 \\
(0.530)\end{array}$ \\
\hline Capital & $\begin{array}{c}0.160 \\
(0.178)\end{array}$ & $\begin{array}{c}0.150 \\
(0.178)\end{array}$ & $\begin{array}{c}0.175 \\
(0.178)\end{array}$ & $\begin{array}{c}0.147 \\
(0.178)\end{array}$ \\
\hline Size & $\begin{array}{c}-0.0942^{* * *} \\
(0.0240)\end{array}$ & $\begin{array}{c}-0.0894 * * * \\
(0.0241)\end{array}$ & $\begin{array}{c}-0.0890^{* * *} \\
(0.0241)\end{array}$ & $\begin{array}{c}-0.111^{* * *} \\
(0.0240)\end{array}$ \\
\hline Board size & $\begin{array}{c}-0.0520^{* * *} \\
(0.00984)\end{array}$ & $\begin{array}{c}-0.0528^{* * *} \\
(0.00989)\end{array}$ & $\begin{array}{c}-0.0540^{* * *} \\
(0.0101)\end{array}$ & $\begin{array}{c}-0.0439^{* * * *} \\
(0.00983)\end{array}$ \\
\hline Board independence & $\begin{array}{l}0.000149 \\
(0.00101)\end{array}$ & $\begin{array}{c}6.17 \mathrm{e}-05 \\
(0.00101)\end{array}$ & $\begin{array}{c}-0.000137 \\
(0.00101)\end{array}$ & $\begin{array}{l}0.000343 \\
(0.00102)\end{array}$ \\
\hline CSR-linked senior pay & $\begin{array}{c}0.0117 \\
(0.0719)\end{array}$ & $\begin{array}{l}0.00742 \\
(0.0720)\end{array}$ & $\begin{array}{l}0.00481 \\
(0.0720)\end{array}$ & $\begin{array}{l}0.00699 \\
(0.0717)\end{array}$ \\
\hline CSR sustainability index & $\begin{array}{l}-0.0677 \\
(0.0561)\end{array}$ & $\begin{array}{l}-0.0703 \\
(0.0561)\end{array}$ & $\begin{array}{l}-0.0606 \\
(0.0560)\end{array}$ & $\begin{array}{l}-0.0625 \\
(0.0560)\end{array}$ \\
\hline Sustainability reporting & $\begin{array}{c}-0.00186 \\
(0.0923)\end{array}$ & $\begin{array}{l}0.00227 \\
(0.0919)\end{array}$ & $\begin{array}{l}-0.0128 \\
(0.0925)\end{array}$ & $\begin{array}{c}0.0144 \\
(0.0929)\end{array}$ \\
\hline GDP growth & $\begin{array}{c}0.0463^{* * *} \\
(0.0138)\end{array}$ & $\begin{array}{c}0.0417 * * * \\
(0.0136)\end{array}$ & $\begin{array}{c}0.0485^{* * *} \\
(0.0142)\end{array}$ & $\begin{array}{c}0.0491 * * * \\
(0.0140)\end{array}$ \\
\hline Economic globalization & $\begin{array}{c}0.566 \\
(0.609)\end{array}$ & $\begin{array}{c}0.821 \\
(0.591)\end{array}$ & $\begin{array}{c}0.900 \\
(0.604)\end{array}$ & $\begin{array}{c}0.442 \\
(0.622)\end{array}$ \\
\hline Shareholder rights & $\begin{array}{c}-0.114 * * * \\
(0.0318)\end{array}$ & $\begin{array}{c}-0.0767^{* *} \\
(0.0353)\end{array}$ & $\begin{array}{c}-0.120^{* * *} \\
(0.0323)\end{array}$ & $\begin{array}{c}-0.160 * * * \\
(0.0307)\end{array}$ \\
\hline RISE & $\begin{array}{l}-0.00152 \\
(0.00505)\end{array}$ & $\begin{array}{l}-0.00449 \\
(0.00533)\end{array}$ & $\begin{array}{c}0.00113 \\
(0.00502)\end{array}$ & $\begin{array}{c}0.00126 \\
(0.00482)\end{array}$ \\
\hline Observations & 1,693 & 1,693 & 1,693 & 1,693 \\
\hline Industry dummies & YES & YES & YES & YES \\
\hline Time dummies & YES & YES & YES & YES \\
\hline R-sq. & 0.0300 & 0.0300 & 0.0287 & 0.0303 \\
\hline
\end{tabular}

Notes: Ordered probit results from Eq. (1) when enhanced with additional CSR-related variables. Column 1 reports results when the key independent variable is the overall ECP measure. Columns 2-4 report results when the overall ECP measure is decomposed into the Environmental, Climate and Policy sub-indices, respectively. All financial variables are winsorized at the 10th and 90th percentiles. The variables are defined in Table 1. Robust standard errors are reported in parentheses.

$* * * \mathrm{p}<0.01$.

$* * \mathrm{p}<0.05$

controversies reported in the media, it is plausible that the level of dissemination of such incidents in a country may drive our results. While it is not possible to examine the exact content reported, we attempt to account for the dissemination of information in a country with a proxy that captures the breadth of print and broadcast perspectives (Press). We explore the extent to which this measure moderates the impact of public perceptions on companies' reputational exposure. The coefficient of the interaction term is insignificant or only marginally significant, revealing a rather weak role in further explaining the aforementioned relationship. Nonetheless, when Press enters the regression as an additional control variable, the coefficients of the key variables of interest remain intact in both sign and significance. We do not tabulate these results to conserve space, but they are available upon request.

We also test how differences in reputation across countries could be explained by variation in the level of institutional development (Deephouse, 


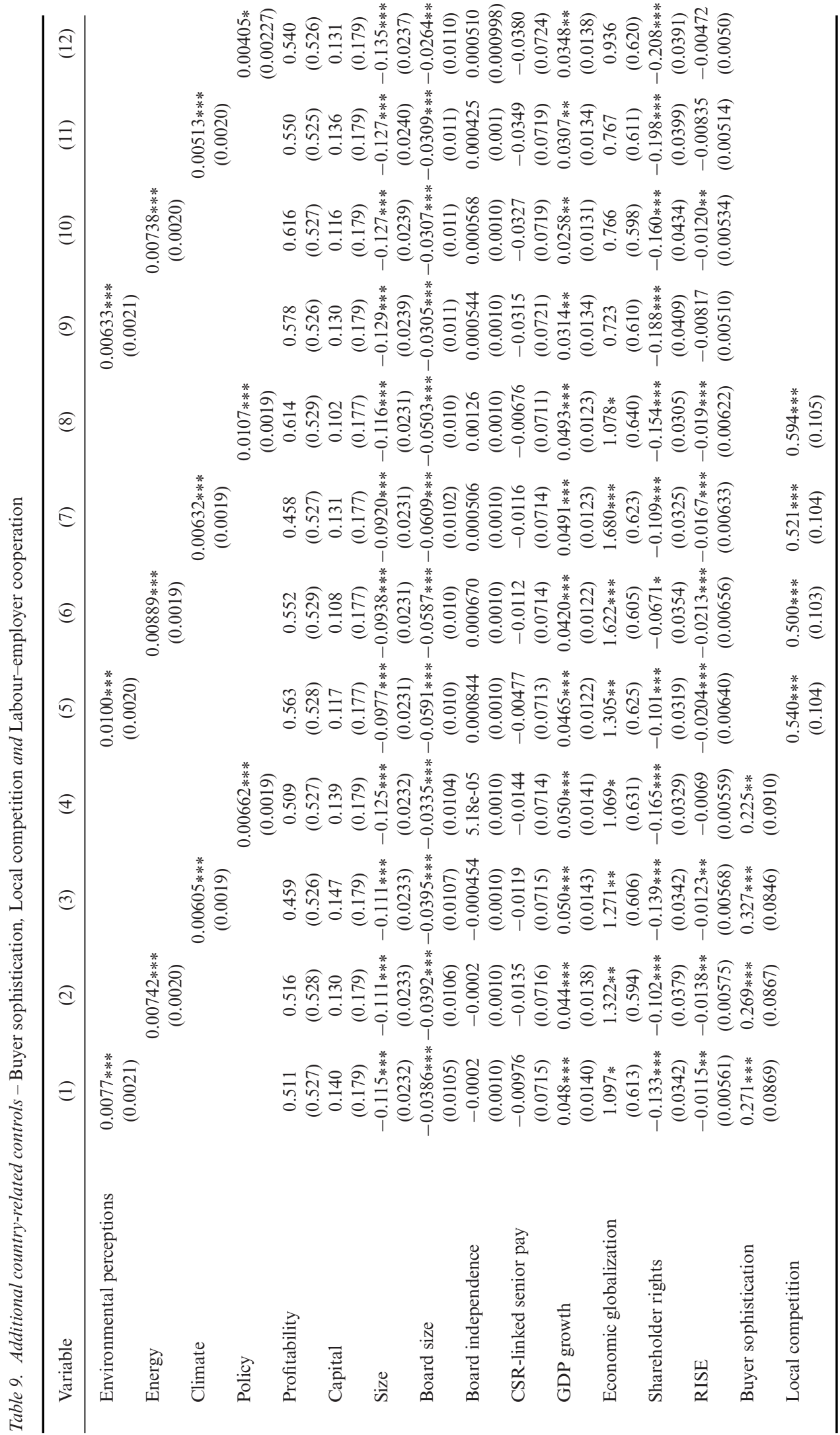




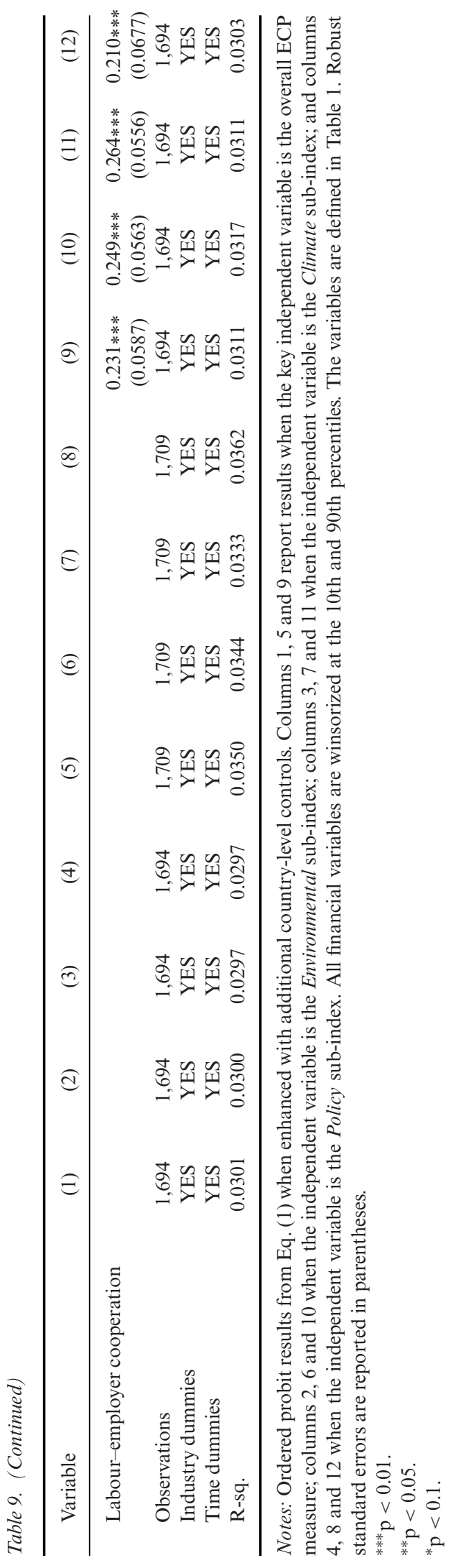


Table 10. Additional country-related controls-poverty

\begin{tabular}{|c|c|c|c|c|}
\hline Variable & (1) & (2) & (3) & (4) \\
\hline Environmental perceptions & $\begin{array}{c}0.0113 * * * \\
(0.00241)\end{array}$ & & & \\
\hline Energy & & $\begin{array}{c}0.00994 * * * \\
(0.00226)\end{array}$ & & \\
\hline Climate & & & $\begin{array}{c}0.00932 * * * \\
(0.00236)\end{array}$ & \\
\hline Policy & & & & $\begin{array}{c}0.00967 * * * \\
(0.00230)\end{array}$ \\
\hline Profitability & $\begin{array}{c}0.408 \\
(0.639)\end{array}$ & $\begin{array}{c}0.427 \\
(0.641)\end{array}$ & $\begin{array}{c}0.313 \\
(0.637)\end{array}$ & $\begin{array}{c}0.381 \\
(0.638)\end{array}$ \\
\hline Capital & $\begin{array}{c}0.114 \\
(0.210)\end{array}$ & $\begin{array}{c}0.102 \\
(0.210)\end{array}$ & $\begin{array}{c}0.131 \\
(0.210)\end{array}$ & $\begin{array}{c}0.112 \\
(0.210)\end{array}$ \\
\hline Size & $\begin{array}{c}-0.130^{* * *} \\
(0.0283)\end{array}$ & $\begin{array}{c}-0.125^{* * *} \\
(0.0284)\end{array}$ & $\begin{array}{c}-0.122 * * * \\
(0.0285)\end{array}$ & $\begin{array}{c}-0.148^{* * *} \\
(0.0283)\end{array}$ \\
\hline Board size & $\begin{array}{c}-0.0393 * * * \\
(0.0120)\end{array}$ & $\begin{array}{c}-0.0407 * * * \\
(0.0121)\end{array}$ & $\begin{array}{c}-0.0446 * * * \\
(0.0122)\end{array}$ & $\begin{array}{c}-0.0291 * * \\
(0.0121)\end{array}$ \\
\hline Board independence & $\begin{array}{l}0.000795 \\
(0.00117)\end{array}$ & $\begin{array}{l}0.000525 \\
(0.00116)\end{array}$ & $\begin{array}{l}0.000465 \\
(0.00116)\end{array}$ & $\begin{array}{c}0.00108 \\
(0.00117)\end{array}$ \\
\hline CSR-linked senior pay & $\begin{array}{c}0.0661 \\
(0.0890)\end{array}$ & $\begin{array}{c}0.0645 \\
(0.0894)\end{array}$ & $\begin{array}{c}0.0658 \\
(0.0891)\end{array}$ & $\begin{array}{c}0.0566 \\
(0.0886)\end{array}$ \\
\hline GDP growth & $\begin{array}{c}0.0473^{* * *} \\
(0.0152)\end{array}$ & $\begin{array}{c}0.0427 * * * \\
(0.0149)\end{array}$ & $\begin{array}{c}0.0500^{* * *} \\
(0.0156)\end{array}$ & $\begin{array}{c}0.0500 * * * \\
(0.0155)\end{array}$ \\
\hline Economic globalization & $\begin{array}{l}-0.388 \\
(0.768)\end{array}$ & $\begin{array}{c}0.154 \\
(0.726)\end{array}$ & $\begin{array}{l}-0.298 \\
(0.772)\end{array}$ & $\begin{array}{l}-0.369 \\
(0.789)\end{array}$ \\
\hline Shareholder rights & $\begin{array}{c}-0.101 * * * \\
(0.0391)\end{array}$ & $\begin{array}{l}-0.0604 \\
(0.0424)\end{array}$ & $\begin{array}{c}-0.0969^{* *} \\
(0.0398)\end{array}$ & $\begin{array}{c}-0.158^{* * *} \\
(0.0391)\end{array}$ \\
\hline RISE & $\begin{array}{c}-0.0136^{* *} \\
(0.00604)\end{array}$ & $\begin{array}{c}-0.0151^{* *} \\
(0.00623)\end{array}$ & $\begin{array}{c}-0.0120^{* *} \\
(0.00611)\end{array}$ & $\begin{array}{l}-0.00917 \\
(0.00572)\end{array}$ \\
\hline Poverty & $\begin{array}{c}-0.257 * * \\
(0.103)\end{array}$ & $\begin{array}{c}-0.220 * * \\
(0.103)\end{array}$ & $\begin{array}{c}-0.295 * * * \\
(0.104)\end{array}$ & $\begin{array}{c}-0.237 * * \\
(0.103)\end{array}$ \\
\hline Observations & 1,204 & 1,204 & 1,204 & 1,204 \\
\hline Industry dummies & YES & YES & YES & YES \\
\hline Time dummies & YES & YES & YES & YES \\
\hline R-sq. & 0.0387 & 0.0383 & 0.0381 & 0.0380 \\
\hline
\end{tabular}

Notes: Ordered probit results from Eq. (1) when enhanced with additional country-level controls. Column 1 reports results when the key independent variable is the overall ECP measure. Columns 2-4 report results when the overall ECP measure is decomposed into the Environmental, Climate and Policy sub-indices, respectively. All financial variables are winsorized at the 10th and 90th percentiles. The variables are defined in Table 1. Robust standard errors are reported in parentheses.

$* * * \mathrm{p}<0.01$.

$* * \mathrm{p}<0.05$.

Newburry and Soleimani, 2016). As in past studies, we use the World Bank's WGI as a measure of each country's overall institutional attainment. The interaction terms of $W G I$ are positive and statistically significant at the 5\% level (except for Pol$i c y)$, indicating that the impact of environmental perceptions on the reputational risk rating is enhanced in countries with high (compared to low) levels of institutional development. The results are reported in Table 11.

Altering the sample. As discussed above, our main dependent variable has no time-series varia- tion. Our panel-setting approach is consistent with many studies examining the impact of national culture on firm outcomes, under the assumption that such social norms change little (if at all) over short time periods (Chen et al., 2015; Deephouse, Newburry and Soleimani, 2016; El Ghoul and Zheng, 2016). Still, running the regressions with firm-year observations over 4 years could artificially increase the power of the tests. Therefore, we re-estimate the baseline regression using values averaged over the 5-year period, giving one observation per firm. Additionally, we re-estimate our 
Table 11. The moderating effect of institutional development levels (WGI)

\begin{tabular}{|c|c|c|c|c|}
\hline Variable & (1) & (2) & (3) & (4) \\
\hline Environmental perceptions & $\begin{array}{l}-0.00568 \\
(0.00418)\end{array}$ & & & \\
\hline WGI & $\begin{array}{c}0.189 \\
(0.130)\end{array}$ & $\begin{array}{c}0.189 \\
(0.120)\end{array}$ & $\begin{array}{c}0.132 \\
(0.123)\end{array}$ & $\begin{array}{c}0.218 \\
(0.163)\end{array}$ \\
\hline Environmental $\times$ WGI & $\begin{array}{c}0.00597^{* *} \\
(0.00282)\end{array}$ & & & \\
\hline Energy & & $\begin{array}{l}-0.00295 \\
(0.00319)\end{array}$ & & \\
\hline Energy $\times$ WGI & & $\begin{array}{c}0.00538^{* *} \\
(0.00232)\end{array}$ & & \\
\hline Climate & & & $\begin{array}{c}-0.00619^{*} \\
(0.00353)\end{array}$ & \\
\hline Climate $\times$ WGI & & & $\begin{array}{c}0.00716^{* * * *} \\
(0.00267)\end{array}$ & \\
\hline Policy & & & & $\begin{array}{c}-0.0107 \\
(0.00701)\end{array}$ \\
\hline Policy $\times$ WGI & & & & $\begin{array}{c}0.00699 \\
(0.00437)\end{array}$ \\
\hline Profitability & $\begin{array}{c}0.533 \\
(0.524)\end{array}$ & $\begin{array}{c}0.534 \\
(0.524)\end{array}$ & $\begin{array}{c}0.521 \\
(0.524)\end{array}$ & $\begin{array}{c}0.522 \\
(0.525)\end{array}$ \\
\hline Capital & $\begin{array}{l}0.0741 \\
(0.176)\end{array}$ & $\begin{array}{l}0.0720 \\
(0.176)\end{array}$ & $\begin{array}{l}0.0738 \\
(0.176)\end{array}$ & $\begin{array}{l}0.0721 \\
(0.176)\end{array}$ \\
\hline Size & $\begin{array}{c}-0.135^{* * *} \\
(0.0237)\end{array}$ & $\begin{array}{c}-0.132 * * * \\
(0.0236)\end{array}$ & $\begin{array}{c}-0.135^{* * *} \\
(0.0236)\end{array}$ & $\begin{array}{c}-0.134 * * * \\
(0.0240)\end{array}$ \\
\hline Board size & $\begin{array}{c}-0.0266^{* *} \\
(0.0108)\end{array}$ & $\begin{array}{c}-0.0292^{* * *} \\
(0.0108)\end{array}$ & $\begin{array}{c}-0.0281^{* *} \\
(0.0110)\end{array}$ & $\begin{array}{c}-0.0239^{* *} \\
(0.0106)\end{array}$ \\
\hline Board independence & $\begin{array}{c}-3.74 \mathrm{e}-05 \\
(0.00101)\end{array}$ & $\begin{array}{c}-2.85 \mathrm{e}-05 \\
(0.00101)\end{array}$ & $\begin{array}{l}5.50 \mathrm{e}-05 \\
(0.00100)\end{array}$ & $\begin{array}{c}-0.000271 \\
(0.00102)\end{array}$ \\
\hline CSR-linked senior pay & $\begin{array}{l}-0.0350 \\
(0.0717)\end{array}$ & $\begin{array}{l}-0.0298 \\
(0.0716)\end{array}$ & $\begin{array}{l}-0.0302 \\
(0.0714)\end{array}$ & $\begin{array}{l}-0.0469 \\
(0.0715)\end{array}$ \\
\hline GDP growth & $\begin{array}{c}0.0300^{* *} \\
(0.0135)\end{array}$ & $\begin{array}{c}0.0295^{* *} \\
(0.0133)\end{array}$ & $\begin{array}{c}0.0324 * * \\
(0.0136)\end{array}$ & $\begin{array}{l}0.0258^{*} \\
(0.0134)\end{array}$ \\
\hline Economic globalization & $\begin{array}{c}0.759 \\
(0.619)\end{array}$ & $\begin{array}{c}0.713 \\
(0.603)\end{array}$ & $\begin{array}{c}0.695 \\
(0.616)\end{array}$ & $\begin{array}{c}0.973 \\
(0.629)\end{array}$ \\
\hline Shareholder rights & $\begin{array}{c}-0.166^{* * *} \\
(0.0376)\end{array}$ & $\begin{array}{c}-0.153 * * * \\
(0.0404)\end{array}$ & $\begin{array}{c}-0.163 * * * \\
(0.0357)\end{array}$ & $\begin{array}{c}-0.163 * * * \\
(0.0374)\end{array}$ \\
\hline RISE & $\begin{array}{c}-0.0100^{*} \\
(0.00554)\end{array}$ & $\begin{array}{c}-0.0120^{* *} \\
(0.00544)\end{array}$ & $\begin{array}{c}-0.00971^{*} \\
(0.00551)\end{array}$ & $\begin{array}{c}-0.0102 * \\
(0.00588)\end{array}$ \\
\hline Observations & 1,709 & 1,709 & 1,709 & 1,709 \\
\hline Industry dummies & YES & YES & YES & YES \\
\hline Time dummies & YES & YES & YES & YES \\
\hline R-sq. & 0.0358 & 0.0360 & 0.0362 & 0.0355 \\
\hline
\end{tabular}

Notes: Ordered probit results from Eq. (1) when including institutional development as a moderator variable. Column 1 reports results when the key independent variable is the overall ECP measure. Columns $2-4$ report results when the overall ECP measure is decomposed into the Environmental, Climate and Policy sub-indices, respectively. All financial variables are winsorized at the 10th and 90th percentiles. The variables are defined in Table 1. Robust standard errors are reported in parentheses.

*** $\mathrm{p}<0.01$.

** $\mathrm{p}<0.05$.

$* \mathrm{p}<0.1$.

baseline regression by averaging the variables per country and year. The results in Tables 12 and 13 show that our findings are robust to these alternative estimations.
Furthermore, to ensure that the results are not driven by a single country, we estimate our regression by excluding the UK, as the dominant country in our sample ( $34 \%$ of observations). As 
Table 12. Averaged values (1)

\begin{tabular}{|c|c|c|c|c|}
\hline Variable & (1) & (2) & (3) & (4) \\
\hline $\begin{array}{l}\text { Environmental perceptions } \\
\quad \text { (avg) }\end{array}$ & $\begin{array}{l}0.0629 * * * \\
(0.00308)\end{array}$ & & & \\
\hline Energy (avg) & & $\begin{array}{r}0.0420 * * * \\
(0.00285)\end{array}$ & & \\
\hline Climate (avg) & & & $\begin{array}{c}0.0519 * * * \\
(0.00298)\end{array}$ & \\
\hline Policy (avg) & & & & $\begin{array}{c}0.0622 * * * \\
(0.00333)\end{array}$ \\
\hline Profitability (avg) & $\begin{array}{c}2.233 \\
(2.478)\end{array}$ & $\begin{array}{c}0.445 \\
(2.628)\end{array}$ & $\begin{array}{c}3.489 \\
(2.496)\end{array}$ & $\begin{array}{l}1.957 \\
(2.625)\end{array}$ \\
\hline Capital (avg) & $\begin{array}{c}15.60 * * * \\
(0.912)\end{array}$ & $\begin{array}{c}13.67 * * * \\
(0.923)\end{array}$ & $\begin{array}{c}14.19 * * * \\
(0.938)\end{array}$ & $\begin{array}{c}15.87 * * * \\
(1.016)\end{array}$ \\
\hline Size (avg) & $\begin{array}{c}0.222^{* * * *} \\
(0.0581)\end{array}$ & $\begin{array}{c}0.148 * * * \\
(0.0526)\end{array}$ & $\begin{array}{c}-0.173 * * * \\
(0.0505)\end{array}$ & $\begin{array}{l}0.104 * * \\
(0.0522)\end{array}$ \\
\hline Board size (avg) & $\begin{array}{c}-0.187 * * * \\
(0.0206)\end{array}$ & $\begin{array}{c}-0.213^{* * *} \\
(0.0209)\end{array}$ & $\begin{array}{c}-0.00428 \\
(0.0195)\end{array}$ & $\begin{array}{c}-0.150^{* * *} \\
(0.0192)\end{array}$ \\
\hline Board independence (avg) & $\begin{array}{c}0.00115 \\
(0.00163)\end{array}$ & $\begin{array}{c}-0.000978 \\
(0.00155)\end{array}$ & $\begin{array}{c}0.00505^{* * *} \\
(0.00172)\end{array}$ & $\begin{array}{c}0.00275 \\
(0.00169)\end{array}$ \\
\hline CSR-linked senior pay (avg) & $\begin{array}{l}0.702 * * * \\
(0.107)\end{array}$ & $\begin{array}{c}0.586^{* * *} \\
(0.103)\end{array}$ & $\begin{array}{l}0.921^{* * *} \\
(0.0972)\end{array}$ & $\begin{array}{c}0.903 * * * \\
(0.102)\end{array}$ \\
\hline GDP growth (avg) & $\begin{array}{c}0.0502 * * * \\
(0.0138)\end{array}$ & $\begin{array}{c}0.0909 * * * \\
(0.0198)\end{array}$ & $\begin{array}{c}0.114^{* * *} \\
(0.0205)\end{array}$ & $\begin{array}{c}0.0906 * * * \\
(0.0187)\end{array}$ \\
\hline Economic globalization (avg) & $\begin{array}{l}-0.775 \\
(0.608)\end{array}$ & $\begin{array}{l}-1.028 \\
(0.730)\end{array}$ & $\begin{array}{c}-1.442 * * \\
(0.726)\end{array}$ & $\begin{array}{c}-1.847 * * * \\
(0.685)\end{array}$ \\
\hline Shareholder rights (avg) & $\begin{array}{c}-0.412 * * * \\
(0.0313)\end{array}$ & $\begin{array}{c}-0.671 * * * \\
(0.0325)\end{array}$ & $\begin{array}{c}-0.898 * * * \\
(0.0339)\end{array}$ & $\begin{array}{c}-0.676^{* * *} \\
(0.0314)\end{array}$ \\
\hline RISE (avg) & $\begin{array}{c}-0.0326 * * * \\
(0.00586)\end{array}$ & $\begin{array}{l}-0.00315 \\
(0.00617)\end{array}$ & $\begin{array}{c}-0.0184 * * * \\
(0.00600)\end{array}$ & $\begin{array}{c}-0.0196^{* * *} \\
(0.00615)\end{array}$ \\
\hline Observations & 2,322 & 2,322 & 2,322 & 2,322 \\
\hline Industry dummies & YES & YES & YES & YES \\
\hline Time dummies & YES & YES & YES & YES \\
\hline R-sq. & 0.301 & 0.240 & 0.276 & 0.288 \\
\hline
\end{tabular}

Notes: Ordered probit results from Eq. (1) when variables are averaged over the 4-year period. Column 1 reports results when the key independent variable is the overall ECP measure. Columns 2-4 report results when the overall ECP measure is decomposed into the Environmental, Climate and Policy sub-indices, respectively. All financial variables are winsorized at the 10th and 90th percentiles. The variables are defined in Table 1. Robust standard errors are reported in parentheses.

$* * * \mathrm{p}<0.01$.

$* * \mathrm{p}<0.05$.

reported in Table 14, we find no difference in our baseline model. Given the nature of the environmental perception variables, we test a revised specification with standard errors clustered at the country level. As Table 15 reports, the main results hold, with the environmental perception variables being statistically significant for all model variants at the $1 \%$ level.

Endogeneity. A potential endogeneity issue clouds the interpretation of our main results. Although reverse causality is unlikely to be a major issue in our setting, public beliefs and views are arguably influenced by the behaviour or actions of local firms (e.g. the BP oil spill of 2010). In addition, endogeneity could potentially be linked to a spurious relationship due to omitted variable bias and/or measurement error.

To be more precise, a spurious relationship occurs when a third variable creates the appearance of a relationship between two other variables, but this relationship disappears when that third variable is included in the analysis. For example, one may argue that country-level national culture can simultaneously drive both public perception (independent variable) and firm reputational exposure 
Table 13. Averaged values (2)

\begin{tabular}{|c|c|c|c|c|}
\hline Variable & (1) & (2) & (3) & (4) \\
\hline $\begin{array}{l}\text { Environmental perceptions } \\
\quad \text { (avg) }\end{array}$ & $\begin{array}{l}0.0169 * * * \\
(0.00205)\end{array}$ & & & \\
\hline Energy (avg) & & $\begin{array}{r}0.0139 * * * \\
(0.00180)\end{array}$ & & \\
\hline Climate (avg) & & & $\begin{array}{r}0.0104 * * * \\
(0.00184)\end{array}$ & \\
\hline Policy (avg) & & & & $\begin{array}{r}0.0165^{* * *} \\
(0.00208)\end{array}$ \\
\hline Profitability (avg) & $\begin{array}{c}1.861^{* * *} \\
(0.542)\end{array}$ & $\begin{array}{c}1.864 * * * \\
(0.543)\end{array}$ & $\begin{array}{c}1.686^{* * *} \\
(0.536)\end{array}$ & $\begin{array}{c}1.935^{* * *} \\
(0.542)\end{array}$ \\
\hline Capital (avg) & $\begin{array}{l}0.0806 \\
(0.161)\end{array}$ & $\begin{array}{l}0.0555 \\
(0.160)\end{array}$ & $\begin{array}{l}0.0967 \\
(0.161)\end{array}$ & $\begin{array}{l}0.0457 \\
(0.160)\end{array}$ \\
\hline Size (avg) & $\begin{array}{c}-0.101 * * * \\
(0.0218)\end{array}$ & $\begin{array}{c}-0.103 * * * \\
(0.0218)\end{array}$ & $\begin{array}{c}-0.0960^{* * *} \\
(0.0223)\end{array}$ & $\begin{array}{c}-0.132 * * * \\
(0.0211)\end{array}$ \\
\hline Board size (avg) & $\begin{array}{c}-0.0745^{* * *} \\
(0.00907)\end{array}$ & $\begin{array}{c}-0.0732 * * * \\
(0.00904)\end{array}$ & $\begin{array}{c}-0.0787^{* * * *} \\
(0.00961)\end{array}$ & $\begin{array}{c}-0.0565^{* * *} \\
(0.00881)\end{array}$ \\
\hline Board independence (avg) & $\begin{array}{c}-0.00308 * * * \\
(0.000992)\end{array}$ & $\begin{array}{c}-0.00282 * * * \\
(0.000977)\end{array}$ & $\begin{array}{c}-0.00345^{* * *} \\
(0.000997)\end{array}$ & $\begin{array}{c}-0.00252^{* *} \\
(0.000991)\end{array}$ \\
\hline CSR-linked senior pay (avg) & $\begin{array}{c}0.156 \\
(0.0974)\end{array}$ & $\begin{array}{c}0.134 \\
(0.0977)\end{array}$ & $\begin{array}{c}0.126 \\
(0.0979)\end{array}$ & $\begin{array}{c}0.145 \\
(0.0965)\end{array}$ \\
\hline GDP growth (avg) & $\begin{array}{l}0.107 * * * \\
(0.0138)\end{array}$ & $\begin{array}{c}0.0996^{* * *} \\
(0.0139)\end{array}$ & $\begin{array}{l}0.119^{* * *} \\
(0.0142)\end{array}$ & $\begin{array}{c}0.116^{* * *} \\
(0.0138)\end{array}$ \\
\hline Economic globalization (avg) & $\begin{array}{c}-3.587 * * * \\
(1.380)\end{array}$ & $\begin{array}{l}-0.885 \\
(1.201)\end{array}$ & $\begin{array}{l}-1.389 \\
(1.379)\end{array}$ & $\begin{array}{c}-4.469 * * * \\
\quad(1.470)\end{array}$ \\
\hline Shareholder rights (avg) & $\begin{array}{c}-0.159 * * * \\
(0.0262)\end{array}$ & $\begin{array}{c}-0.0979 * * * \\
(0.0287)\end{array}$ & $\begin{array}{c}-0.171 * * * \\
(0.0263)\end{array}$ & $\begin{array}{c}-0.244 * * * \\
(0.0256)\end{array}$ \\
\hline RISE (avg) & $\begin{array}{c}-0.0100^{* *} \\
(0.00426)\end{array}$ & $\begin{array}{c}-0.0106 * * \\
(0.00433)\end{array}$ & $\begin{array}{l}-0.00315 \\
(0.00425)\end{array}$ & $\begin{array}{l}-0.00566 \\
(0.00399)\end{array}$ \\
\hline Observations & 2,196 & 2,196 & 2,196 & 2,196 \\
\hline Industry dummies & YES & YES & YES & YES \\
\hline Time dummies & YES & YES & YES & YES \\
\hline R-sq. & 0.0304 & 0.0299 & 0.0285 & 0.0306 \\
\hline
\end{tabular}

Notes: Ordered probit results from Eq. (1) when variables are averaged on a country-year basis. Column 1 reports results when the key independent variable is the overall ECP measure. Columns 2-4 report results when the overall ECP measure is decomposed into the Environmental, Climate and Policy sub-indices, respectively. All financial variables are winsorized at the 10th and 90th percentiles. The variables are defined in Table 1. Robust standard errors are reported in parentheses.

$* * * \mathrm{p}<0.01$.

** $\mathrm{p}<0.05$.

(dependent variable), thus creating a spurious relationship. To account for this, we include national culture as an additional control variable in the baseline specification. We consider all six dimensions identified by Hofstede (1980), Hofstede and Bond (1988) and Hofstede, Hofstede and Minkov (2010), namely power distance, individualism (versus collectivism), masculinity (versus femininity), uncertainty avoidance, long-term orientation (versus short-term orientation) and indulgence (versus restraint). Since we are interested in controlling for these aspects of national culture rather than testing some hypothesis about their potential impact on corporate reputation exposure, and given the potential correlations between the six dimensions, we resort to principal component analysis. This results in two components with eigenvalues higher than one, explaining in total 0.7684 of the variance. The inclusion of these two cultural components in the regression does not alter our main findings. Thus, it appears that our results are not driven by spurious correlation due to the omission of national culture. The results are reported in Table 16 .

As a further test, to isolate the exogenous component of our endogenous variable and alleviate any remaining concerns about public beliefs being influenced by firm behaviour, we re-estimate 
Table 14. Excluding the UK

\begin{tabular}{|c|c|c|c|c|}
\hline Variable & (1) & (2) & (3) & (4) \\
\hline Environmental perceptions & $\begin{array}{c}0.0121 * * * \\
(0.00232)\end{array}$ & & & \\
\hline Energy & & $\begin{array}{c}0.00845^{* * *} \\
(0.00196)\end{array}$ & & \\
\hline Climate & & & $\begin{array}{c}0.00754 * * * \\
(0.00227)\end{array}$ & \\
\hline Policy & & & & $\begin{array}{r}0.0130 * * * \\
(0.00223)\end{array}$ \\
\hline Profitability & $\begin{array}{l}1.309^{* *} \\
(0.654)\end{array}$ & $\begin{array}{c}1.331^{* *} \\
(0.655)\end{array}$ & $\begin{array}{l}1.132^{*} \\
(0.654)\end{array}$ & $\begin{array}{l}1.368^{* *} \\
(0.653)\end{array}$ \\
\hline Capital & $\begin{array}{c}0.246 \\
(0.217)\end{array}$ & $\begin{array}{c}0.224 \\
(0.217)\end{array}$ & $\begin{array}{c}0.267 \\
(0.218)\end{array}$ & $\begin{array}{c}0.250 \\
(0.217)\end{array}$ \\
\hline Size & $\begin{array}{c}-0.0932 * * * \\
(0.0254)\end{array}$ & $\begin{array}{c}-0.0979 * * * \\
(0.0253)\end{array}$ & $\begin{array}{c}-0.0883^{* * * *} \\
(0.0259)\end{array}$ & $\begin{array}{c}-0.117 * * * \\
(0.0247)\end{array}$ \\
\hline Board size & $\begin{array}{c}-0.0324 * * * \\
(0.00898)\end{array}$ & $\begin{array}{c}-0.0329 * * * \\
(0.00903)\end{array}$ & $\begin{array}{c}-0.0360 * * * \\
(0.00932)\end{array}$ & $\begin{array}{c}-0.0179 * * \\
(0.00912)\end{array}$ \\
\hline Board independence & $\begin{array}{c}0.000142 \\
(0.000990)\end{array}$ & $\begin{array}{c}0.000292 \\
(0.000987)\end{array}$ & $\begin{array}{l}-6.02 \mathrm{e}-05 \\
(0.000990)\end{array}$ & $\begin{array}{c}0.000463 \\
(0.000994)\end{array}$ \\
\hline CSR-linked senior pay & $\begin{array}{c}-0.115 \\
(0.0879)\end{array}$ & $\begin{array}{l}-0.109 \\
(0.0885)\end{array}$ & $\begin{array}{l}-0.113 \\
(0.0880)\end{array}$ & $\begin{array}{c}-0.125 \\
(0.0874)\end{array}$ \\
\hline GDP growth & $\begin{array}{c}0.0455^{* * * *} \\
(0.00990)\end{array}$ & $\begin{array}{c}0.0375 * * * \\
(0.00963)\end{array}$ & $\begin{array}{c}0.0449 * * * \\
(0.0102)\end{array}$ & $\begin{array}{c}0.0502^{* * * *} \\
(0.0101)\end{array}$ \\
\hline Economic globalization & $\begin{array}{c}2.503 * * * \\
(0.749)\end{array}$ & $\begin{array}{c}2.577 * * * \\
(0.745)\end{array}$ & $\begin{array}{c}2.725^{* * * *} \\
(0.746)\end{array}$ & $\begin{array}{c}2.315^{* * * *} \\
(0.759)\end{array}$ \\
\hline Shareholder rights & $\begin{array}{c}-0.120 * * * \\
(0.0279)\end{array}$ & $\begin{array}{c}-0.0799 * * * \\
(0.0308)\end{array}$ & $\begin{array}{c}-0.120^{* * *} \\
(0.0281)\end{array}$ & $\begin{array}{c}-0.191 * * * \\
(0.0293)\end{array}$ \\
\hline RISE & $\begin{array}{c}-0.0140 * * \\
(0.00643)\end{array}$ & $\begin{array}{l}-0.00963 \\
(0.00623)\end{array}$ & $\begin{array}{l}-0.00779 \\
(0.00645)\end{array}$ & $\begin{array}{c}-0.0134 * * \\
(0.00599)\end{array}$ \\
\hline Observations & 1,442 & 1,442 & 1,442 & 1,442 \\
\hline Industry dummies & YES & YES & YES & YES \\
\hline Time dummies & YES & YES & YES & YES \\
\hline R-sq. & 0.0439 & 0.0426 & 0.0418 & 0.0450 \\
\hline
\end{tabular}

Notes: Ordered probit results from Eq. (1) when excluding the UK from the sample. Column 1 reports results when the key independent variable is the overall ECP measure. Columns 2-4 report results when the overall ECP measure is decomposed into the Environmental, Climate and Policy sub-indices, respectively. All financial variables are winsorized at the 10th and 90th percentiles. The variables are defined in Table 1. Robust standard errors are reported in parentheses.

$* * * \mathrm{p}<0.01$.

${ }^{* *} \mathrm{p}<0.05$.

$* \mathrm{p}<0.1$.

the baseline model presented in Eq. (1) with an ordered probit regression that allows for endogenous covariates. ${ }^{16}$ We propose that the disaster intensity measure for temperature extremes from Felbermayr and Gröschl (2014) can serve as an appropriate instrument. Felbermayr and Gröschl (2014) estimate this index (Temp) as the percentage difference between the maximum temperature in 1 month and the corresponding long-run (1979-2010) monthly mean. Strong positive de-

${ }^{16}$ For a more detailed discussion of the model, see Wooldridge (2010). viations are interpreted as heat waves and strong negative deviations as cold waves. We rely on this instrument for two reasons. First, it would be difficult for someone to argue that extreme temperatures may influence directly corporate reputational exposure. Thus, this instrument satisfies the exogeneity requirement. Second, the literature suggests that people's personal experience of natural hazards or climate change is related to their attitude on climate change and climate policy, their confidence that their actions will affect climate change, and their willingness to save energy to mitigate climate change (Lujala, Lein and Ketil 
Table 15. Clustering standard errors at the country level

\begin{tabular}{|c|c|c|c|c|}
\hline Variable & (1) & (2) & (3) & (4) \\
\hline Environmental perceptions & $\begin{array}{c}0.00878 * * * \\
(0.00260)\end{array}$ & & & \\
\hline Energy & & $\begin{array}{c}0.00813^{* * *} \\
(0.00248)\end{array}$ & & \\
\hline Climate & & & $\begin{array}{c}0.00578 * * \\
(0.00258)\end{array}$ & \\
\hline Policy & & & & $\begin{array}{c}0.00835^{* * * *} \\
(0.00299)\end{array}$ \\
\hline Profitability & $\begin{array}{c}0.464 \\
(0.706)\end{array}$ & $\begin{array}{c}0.477 \\
(0.722)\end{array}$ & $\begin{array}{c}0.373 \\
(0.673)\end{array}$ & $\begin{array}{c}0.458 \\
(0.704)\end{array}$ \\
\hline Capital & $\begin{array}{c}0.182 \\
(0.191)\end{array}$ & $\begin{array}{c}0.168 \\
(0.189)\end{array}$ & $\begin{array}{c}0.196 \\
(0.190)\end{array}$ & $\begin{array}{c}0.173 \\
(0.192)\end{array}$ \\
\hline Size & $\begin{array}{c}-0.0931^{* *} \\
(0.0370)\end{array}$ & $\begin{array}{c}-0.0893^{* *} \\
(0.0376)\end{array}$ & $\begin{array}{c}-0.0871^{* *} \\
(0.0384)\end{array}$ & $\begin{array}{c}-0.108 * * * \\
(0.0336)\end{array}$ \\
\hline Board size & $\begin{array}{c}-0.0480 * * * \\
(0.0158)\end{array}$ & $\begin{array}{c}-0.0487 * * * \\
(0.0168)\end{array}$ & $\begin{array}{c}-0.0500 * * * \\
(0.0163)\end{array}$ & $\begin{array}{c}-0.0394^{* *} \\
(0.0156)\end{array}$ \\
\hline Board independence & $\begin{array}{l}0.000499 \\
(0.00109)\end{array}$ & $\begin{array}{l}0.000370 \\
(0.00105)\end{array}$ & $\begin{array}{l}0.000236 \\
(0.00107)\end{array}$ & $\begin{array}{l}0.000745 \\
(0.00115)\end{array}$ \\
\hline CSR-linked senior pay & $\begin{array}{l}-0.0498 \\
(0.0991)\end{array}$ & $\begin{array}{l}-0.0535 \\
(0.1000)\end{array}$ & $\begin{array}{l}-0.0540 \\
(0.0984)\end{array}$ & $\begin{array}{c}-0.0527 \\
(0.100)\end{array}$ \\
\hline GDP growth & $\begin{array}{c}0.0397 * * * \\
(0.0112)\end{array}$ & $\begin{array}{c}0.0362^{* * *} \\
(0.0106)\end{array}$ & $\begin{array}{c}0.0409^{* * * *} \\
(0.0131)\end{array}$ & $\begin{array}{c}0.0417 * * * \\
(0.0121)\end{array}$ \\
\hline Economic globalization & $\begin{array}{c}0.915 \\
(0.836)\end{array}$ & $\begin{array}{l}1.210 \\
(0.797)\end{array}$ & $\begin{array}{l}1.219 \\
(0.811)\end{array}$ & $\begin{array}{c}0.777 \\
(0.872)\end{array}$ \\
\hline Shareholder rights & $\begin{array}{c}-0.107 * * * \\
(0.0396)\end{array}$ & $\begin{array}{l}-0.0740 \\
(0.0493)\end{array}$ & $\begin{array}{c}-0.111^{* * *} \\
(0.0422)\end{array}$ & $\begin{array}{c}-0.151^{* * *} \\
(0.0341)\end{array}$ \\
\hline RISE & $\begin{array}{l}-0.00105 \\
(0.00917)\end{array}$ & $\begin{array}{l}-0.00330 \\
(0.00903)\end{array}$ & $\begin{array}{c}0.00168 \\
(0.00962)\end{array}$ & $\begin{array}{c}0.00157 \\
(0.00892)\end{array}$ \\
\hline Observations & 2,025 & 2,025 & 2,025 & 2,025 \\
\hline Industry dummies & YES & YES & YES & YES \\
\hline Time dummies & YES & YES & YES & YES \\
\hline R-sq. & 0.0320 & 0.0318 & 0.0309 & 0.0322 \\
\hline
\end{tabular}

Notes: Ordered probit results from Eq. (1) when clustering standard errors at the country level. Column 1 reports results when the key independent variable is the overall ECP measure. Columns 2-4 report results when the overall ECP measure is decomposed into the Environmental, Climate and Policy sub-indices, respectively. All financial variables are winsorized at the 10th and 90th percentiles. The variables are defined in Table 1. Robust standard errors are reported in parentheses.

$* * * \mathrm{p}<0.01$.

** $\mathrm{p}<0.05$.

Rød, 2015; Spence, Poortinga and Pidgeon, 2011); a growing number of studies from this strand of the literature focus on temperature variations (Hamilton and Keim, 2009; Howe et al., 2013; Leiserowitz, 2006; Weber, 2016). Thus, this instrument should satisfy the relevance requirement of an instrument.

Columns $1-4$ in Table 17 report our findings, with Panel A presenting the second-stage results and Panel B the first-stage results. The key variable of interest (Environmental perceptions) retains its sign and significance, and the results remain intact for the three sub-indices of Energy, Climate and
Policy. We also find that the instrument Temp is positively related to all four environmental perception variables at the $1 \%$ level, thus confirming its impact on the first-stage regression-dependent variable. Given the lack of a formal set of tests to confirm the validity of the instrument, we re-estimate the first-stage model and examine the likelihood ratio chi-square statistic. We obtain a value lower than 0.001 , which confirms the significance of the model. Finally, in untabulated results, we also estimate our model using a two-stage least-squares (2SLS) linear model. Although the 2SLS method disregards the ordinal nature of 
Table 16. Controlling for national culture

\begin{tabular}{|c|c|c|c|c|}
\hline Variables & (1) & (2) & (3) & (4) \\
\hline Environmental perception & $\begin{array}{c}0.00650^{* * *} \\
(0.00200)\end{array}$ & & & \\
\hline Energy & & $\begin{array}{c}0.00613^{* * *} \\
(0.00200)\end{array}$ & & \\
\hline Climate & & & $\begin{array}{c}0.00511^{* * *} \\
(0.00184)\end{array}$ & \\
\hline Policy & & & & $\begin{array}{c}0.00571^{* * *} \\
(0.00189)\end{array}$ \\
\hline Profitability & $\begin{array}{c}0.628 \\
(0.532)\end{array}$ & $\begin{array}{c}0.626 \\
(0.532)\end{array}$ & $\begin{array}{c}0.591 \\
(0.531)\end{array}$ & $\begin{array}{c}0.618 \\
(0.532)\end{array}$ \\
\hline Capital & $\begin{array}{l}0.0835 \\
(0.178)\end{array}$ & $\begin{array}{l}0.0750 \\
(0.178)\end{array}$ & $\begin{array}{l}0.0940 \\
(0.178)\end{array}$ & $\begin{array}{l}0.0759 \\
(0.178)\end{array}$ \\
\hline Size & $\begin{array}{c}-0.0867 * * * \\
(0.0237)\end{array}$ & $\begin{array}{c}-0.0842 * * * \\
(0.0238)\end{array}$ & $\begin{array}{c}-0.0806^{* * *} \\
(0.0239)\end{array}$ & $\begin{array}{c}-0.0971^{* * *} \\
(0.0239)\end{array}$ \\
\hline Board size & $\begin{array}{c}-0.0404^{* * * *} \\
(0.0104)\end{array}$ & $\begin{array}{c}-0.0406^{* * *} \\
(0.0105)\end{array}$ & $\begin{array}{c}-0.0420 \text { *** } \\
(0.0107)\end{array}$ & $\begin{array}{c}-0.0356^{* * *} \\
(0.0103)\end{array}$ \\
\hline Board independence & $\begin{array}{c}-0.00191^{*} \\
(0.00110)\end{array}$ & $\begin{array}{c}-0.00203^{*} \\
(0.00110)\end{array}$ & $\begin{array}{c}-0.00211^{*} \\
(0.00109)\end{array}$ & $\begin{array}{l}-0.00171 \\
(0.00111)\end{array}$ \\
\hline Senior ex. compensation - CSR & $\begin{array}{c}0.0118 \\
(0.0734)\end{array}$ & $\begin{array}{l}0.00914 \\
(0.0735)\end{array}$ & $\begin{array}{l}0.00714 \\
(0.0733)\end{array}$ & $\begin{array}{l}0.00985 \\
(0.0733)\end{array}$ \\
\hline GDP growth & $\begin{array}{r}0.0321 * * \\
(0.0134)\end{array}$ & $\begin{array}{l}0.0289 * * \\
(0.0133)\end{array}$ & $\begin{array}{l}0.0317^{* *} \\
(0.0134)\end{array}$ & $\begin{array}{c}0.0360^{* * * *} \\
(0.0138)\end{array}$ \\
\hline Econ. globalization & $\begin{array}{c}1.565^{* *} \\
(0.631)\end{array}$ & $\begin{array}{c}1.756^{* * *} \\
(0.614)\end{array}$ & $\begin{array}{c}1.750^{* * *} \\
(0.622)\end{array}$ & $\begin{array}{l}1.507^{* *} \\
(0.646)\end{array}$ \\
\hline Shareholder & $\begin{array}{c}-0.213^{* * *} \\
(0.0389)\end{array}$ & $\begin{array}{c}-0.184 * * * \\
(0.0440)\end{array}$ & $\begin{array}{c}-0.224 * * * \\
(0.0381)\end{array}$ & $\begin{array}{c}-0.239^{* * *} \\
(0.0364)\end{array}$ \\
\hline RISE & $\begin{array}{c}-0.0277 * * * \\
(0.00686)\end{array}$ & $\begin{array}{c}-0.0288^{* * * *} \\
(0.00694)\end{array}$ & $\begin{array}{c}-0.0291 * * * \\
(0.00691)\end{array}$ & $\begin{array}{c}-0.0241^{* * *} \\
(0.00689)\end{array}$ \\
\hline CULTPCA1 & $\begin{array}{c}-0.147 * * * \\
(0.0278)\end{array}$ & $\begin{array}{c}-0.144 * * * \\
(0.0281)\end{array}$ & $\begin{array}{c}-0.162 * * * \\
(0.0271)\end{array}$ & $\begin{array}{c}-0.137 * * * \\
(0.0286)\end{array}$ \\
\hline CULTPCA2 & $\begin{array}{c}0.0926 * * \\
(0.0370)\end{array}$ & $\begin{array}{c}0.0854 * * \\
(0.0376)\end{array}$ & $\begin{array}{c}0.106 * * * \\
(0.0362)\end{array}$ & $\begin{array}{c}0.0900 * * \\
(0.0370)\end{array}$ \\
\hline Observations & 1,652 & 1,652 & 1,652 & 1,652 \\
\hline Industry dummies & YES & YES & YES & YES \\
\hline Time dummies & YES & YES & YES & YES \\
\hline $\mathrm{R}$-sq & 0.0351 & 0.0350 & 0.0349 & 0.0350 \\
\hline
\end{tabular}

Notes: Ordered probit results from Eq. (1) including national culture as an additional control. Column 1 reports results when the key independent variable is the overall ECP measure. Columns 2-4 report results when the overall ECP measure is decomposed into the Environmental, Climate and Policy sub-indices, respectively. All financial variables are winsorized at the 10th and 90th percentiles. The variables are defined in Table 1. Robust standard errors are reported in parentheses.

$* * * \mathrm{p}<0.01$.

$* * \mathrm{p}<0.05$.

$* \mathrm{p}<0.1$.

our dependent variable, it is still a viable and less complex approach (Angrist and Pischke, 2008). The results in both the first and second stage remain the same in terms of sign and significance. While the 2SLS results should be treated with caution due to the ordinal and categorical nature of the dependent variable, the advantage of this approach lies in allowing us to examine the va- lidity of our instruments. All the relevant tests confirm that our instruments are suitable. ${ }^{17}$

\footnotetext{
${ }^{17}$ For instance, for the overall ECP measure, the Kleibergen-Paap rk LM statistic (p-value) $=0.000$ and the Kleibergen-Paap rk Wald F statistic $=310.366$. Similar results are obtained when we use the sub-indices of Energy, Climate and Policy.
} 
Table 17. Dealing with endogeneity with the use of exogenous instruments

\begin{tabular}{|c|c|c|c|c|}
\hline & I & II & III & IV \\
\hline & \multicolumn{4}{|c|}{ Panel A: Second-stage results } \\
\hline & \multicolumn{4}{|c|}{ Dep. Var: Rep. exposure } \\
\hline Energy & $\begin{array}{c}0.029 * * * \\
(0.0045)\end{array}$ & & & \\
\hline Climate & \multicolumn{3}{|c|}{$\begin{array}{c}0.0374 * * * \\
(0.0054)\end{array}$} & \\
\hline Policy & & \multicolumn{3}{|c|}{$\begin{array}{c}0.0157 * * * \\
(0.0025)\end{array}$} \\
\hline Environmental perceptions & & & & $\begin{array}{r}0.0244 * * * \\
(0.0039)\end{array}$ \\
\hline Controls & YES & YES & YES & YES \\
\hline Industry fixed effects & YES & YES & YES & YES \\
\hline \multirow{3}{*}{$\begin{array}{l}\text { Time fixed effects } \\
\text { Number of observations }\end{array}$} & YES & YES & YES & YES \\
\hline & \multicolumn{4}{|c|}{ Panel B: First-stage results } \\
\hline & $\begin{array}{l}\text { Dep. Var: } \\
\text { Energy }\end{array}$ & $\begin{array}{c}\text { Dep. Var: } \\
\text { Climate }\end{array}$ & $\begin{array}{l}\text { Dep. Var: } \\
\text { Policy }\end{array}$ & $\begin{array}{l}\text { Dep. Var: } \\
\text { ECP }\end{array}$ \\
\hline \multicolumn{5}{|l|}{ Instrument } \\
\hline Temp & $\begin{array}{c}3.808^{* * *} \\
(0.2018)\end{array}$ & $\begin{array}{c}2.727 * * * \\
(0.2385)\end{array}$ & $\begin{array}{l}7.268 * * * \\
(0.1546)\end{array}$ & $\begin{array}{c}4.601 * * * \\
(0.1855)\end{array}$ \\
\hline Controls & YES & YES & YES & YES \\
\hline Industry fixed effects & YES & YES & YES & YES \\
\hline Time fixed effects & YES & YES & YES & YES \\
\hline
\end{tabular}

Notes: Results obtained when estimating an ordered probit model with endogenous covariates. Panel A reports the second-stage results. Panel B reports the first-stage results. Column 1 reports results when the key independent variable is the overall ECP measure. Columns 2-4 report results when the overall ECP measure is decomposed into the Environmental, Climate and Policy sub-indices, respectively. All financial variables are winsorized at the 10th and 90th percentiles. The variables are defined in Table 1. Robust standard errors are reported in parentheses. $* * * \mathrm{p}<0.01$.

\section{Discussion and conclusions}

Corporate reputation has received substantial attention in the management literature. However, little is known about the factors that drive reputational exposure across countries. Based on insights from institutional theory, which has been widely adopted to explain how firm behaviour is being driven by institutional pressures, we aim to fill this gap. We focus on public perceptions of environment-related issues like energy, climate and the adoption of relevant policies. Such beliefs may play the role of informal institutions, since societal expectations regarding organizational behaviour are possibly the most influential environmental forces. For example, as discussed in the latest Authenticity Gap Report by FleishmanHillard Fishburn (2019), campaigns such as Extinction Rebellion, widespread climate protests and grow- ing public concern about single-use plastics and irresponsible energy have driven climate change higher on the global agenda. At the same time, attitudes are driven by a greater emphasis on societal purpose and internal scrutiny from the media, and while consumers do not expect companies to fix everything, they will scrutinize them to make a positive difference on the issues under their control. This means that companies nowadays operate within a fast-changing, possibly extreme, informal institutional environment that poses challenges for the management of value and reputation, and subsequently the corporate governance of firms.

Using a sample of 643 firms from 19 European countries over the period 2015-2018, we find that more environmentally friendly public perceptions result in lower reputational exposure. Drilling down into public perceptions, we find that this result holds when we disaggregate the overall 
index of environmental perceptions to sub-indices of public opinions on energy, climate and the introduction of related policies. The results are robust to various firm-level and country-level control variables, and to techniques that address potential endogeneity bias. One potential explanation of our findings is that environmentally friendly societal beliefs put pressure on managers to adopt proactive environmental strategies and achieve a fit between corporate policies and public expectations. In turn, this results in lower reputational exposure. We also find that age diversity in the board of directors moderates the association between environmentally friendly public perceptions and reputational exposure.

These findings have implications for both firm internal stakeholders, and policy-makers and other external stakeholders. First, our study documents for the first time in the literature that public beliefs regarding environmental issues have an important impact on firm reputational exposure. Policy-makers could take this into account in designing policies for environmental and social issues. Additionally, for governments and regulatory agents, this means that one way to strengthen the effect of public pressure on firm behaviour is to raise managerial and shareholders' awareness of this relationship. Environmental regulations could have a complementary role to public pressure, and they could also be complemented with education programmes and informative campaigns for managers and shareholders. For example, the FleishmanHillard Fishburn (2019) report reveals that $79 \%$ of surveyed consumers are concerned about environmental issues and 59\% expect companies to take a stand on climate change, ranking the protection of the environment in consumers' top three expectations. At the same time, $84 \%$ of the studied firms experience a gap between people's expectations of them in caring for the environment and people's actual experience of what they are doing. Therefore, the report highlights that organizations should take steps to manage together their brand and reputation, and that failure to communicate effectively on the topics that are of interest to the public and consumers means that they risk alienating their customer base. For example, $80 \%$ of consumers are prepared to stop using the products and services of a brand if its response to an issue does not support their personal views. We believe that one potential reason explaining this gap is that while many corporate leaders understand the key role of business in tackling climate change, they also believe that pursuing a sustainability agenda runs counter to the wishes of their shareholders (Eccles and Klimenko, 2019). However, after interviewing 70 senior executives at 43 global institutional investing firms, Eccles and Klimenko (2019) argue that this perception is outdated, with ESG running behind in the agenda of these executives. This is confirmed in a survey by Bank of America Merrill Lynch, which reveals that US executives underestimated substantially the percentage of their company's shares held by firms employing sustainable investing strategies, with the average estimate being 5\% compared to an actual figure closer to 25\% (Eccles and Klimenko, 2019). Appropriately designed programmes and campaigns could increase awareness about these issues, align the interests of all parties and subsequently decrease reputational exposures.

Second, given the relationship between reputation and stock prices established in past studies (Gregory, 1998; Raithel and Schwaiger, 2015), prospective international investors could also consider cross-country differences in public environmental perceptions as these might impact corporate reputation exposure, with subsequent implications for the value of their investment. For example, a recent report by Bank of America Merrill Lynch (2019) highlights that ESG-related scandals can mean huge losses for companies and investors, mentioning that 'Major ESG-related controversies during the past six years were accompanied by peak-to-trough market capitalization losses of \$534 billion for large US companies. Loss avoidance is key for portfolio returns over time' (p. 1).

Third, our research brings together the literature on informal institutions and corporate governance. While corporate governance researchers have been debating the impact of board characteristics on firm performance and reputation, our results show that most of the board and corporate governance characteristics do not have a moderating role in the relationship between the informal institutional pressures of public environmental perceptions and corporate reputational exposure. In more detail, board qualifications, board nationality mix and board gender mix do not have a moderating role, with age diversity being the only board characteristic that matters. Existing shareholders could take these findings into account when adopting corporate governance mechanisms. 
Fourth, our results have shown that the impact of environmental perceptions on reputational risk rating is enhanced in countries with high (compared to low) levels of institutional development. This can have implications for all the above stakeholders. It will also have implications for firm managers, as it shows that the impact of public perceptions on reputational risk is not uniform across countries, and managers will have to take such country-specific characteristics into account while managing reputational risk.

\section{Limitations}

Our study is not without its limitations. First, data availability restricted the analysis to a 4-year period. Future studies could explore if the results hold over longer time periods. Second, public perceptions on environmental issues may vary within a country. While data are currently available only at the country level, future research could possibly consider regional public perceptions and their impact on the reputational risk of locally headquartered corporations. Finally, future research could possibly survey executives to reveal their views and strategic decisions in response to the public's environmental perceptions.

\section{References}

Aharonson, B. S. and S. Bort (2015). 'Institutional pressure and an organization's strategic response in corporate social action engagement: the role of ownership and media attention', Strategic Organization, 13, pp. 307-339.

Angrist, J. D. and J. S. Pischke (2008). Mostly Harmless Econometrics: An Empiricist's Companion. Princeton, NJ: Princeton University Press.

Ashbaugh-Skaife, H., D. Collins and R. LaFond (2006). 'The effects of corporate governance on firms' credit ratings', Journal of Accounting and Economics, 42, pp. 203-243.

Bank of America Merrill Lynch (2019). 'ESG Matters US: 10 reasons you should care about ESG'. Available at https://www.bofaml.com/content/dam/boamlimages/ documents/articles/ID19_1119/esg_matters.pdf [accessed 19 October 2020].

Berkman, H., J. Jona and N. Soderstrom (2019). 'Firm value and government commitment to combating climate change', Pacific-Basin Finance Journal, 53, pp. 297-307.

Bermiss, Y. S., E. J. Zajac and B. G. King (2014). 'Under construction: how commensuration and management fashion affect corporate reputation rankings', Organization Science, 25 , pp. 591-608.

Berrone, P., A. Fosfuri, L. Gelabert and L. R. Gomez-Mejia (2013). 'Necessity as the mother of 'green' inventions: institutional pressures and environmental innovations', Strategic Management Journal, 34, pp. 891-909.
Black, E. L., T. A. Carnes and V. J. Richardson (2000). 'The market valuation of corporate reputation', Corporate Reputation Review, 3, pp. 31-42.

Board of Governors of the Federal Reserve System (1995). 'SR 95 - 51: Rating the adequacy of risk management processes and internal controls at state member banks and bank holding companies'. Available at https://sig.org/federal-reserve-banksr-95-51-rating-adequacy-risk-management-processes-andinternal-controls-state [accessed 20 August 2020]. $<1$

Brammer, S. and S. Pavelin (2004). 'Building a good reputation', European Management Journal, 22, pp. 704-713.

Brammer, S. J. and S. Pavelin (2006). 'Corporate reputation and social performance: the importance of fit', Journal of Management Studies, 43, pp. 435-455.

Brammer, S., G. Jackson and D. Matten (2012). 'Corporate social responsibility and institutional theory: new perspectives on private governance', Socio-Economic Review, 10, pp. 3-28.

Bromiley, P. and D. Rau (2015). 'Social, behavioral, and cognitive influences on upper echelons during strategy process: a literature review', Journal of Management, 42, pp. 174-202.

Buttel, F. H. (1979). 'Age and environmental concern: a multivariate analysis', Youth \& Society, 10, pp. 237-256.

Cao, Y., N. J. Myers, A. L. Myers and C. T. Omer (2015). 'Company reputation and the cost of equity capital', Review of Accounting Studies, 20, pp. 42-81.

Carney, M. (2019). 'Firms ignoring climate crisis will go bankrupt', The Guardian, 13 October. Available at https: //www.theguardian.com/environment/2019/oct/13/firmsignoring-climate-crisis-bankrupt-mark-carney-bankengland-governor [accessed 20 August 2020].

Carpenter, M. A., M. A. Geletkanycz and W. G. Sanders (2004). 'Upper echelons research revisited: antecedents, elements, and consequences of top management team composition', Journal of Management, 30, pp. 749-778.

Chen, X., N. Yi, L. Zhang and D. Li (2018). 'Does institutional pressure foster corporate green innovation? Evidence from China's top 100 companies', Journal of Cleaner Production, 188, pp. 304-311.

Chen, Y., P. Y. Dou, S. G. Rhee, C. Truong and M. Veeraraghavan (2015). 'National culture and corporate cash holdings around the world', Journal of Banking and Finance, 50, pp. 1-18.

Daddi, T., F. Testa, M. Frey and F. Iraldo (2016). 'Exploring the link between institutional pressures and environmental management systems effectiveness: an empirical study', Journal of Environmental Management, 183, pp. 647-656.

Daddi, T., R. Bleischwitz, N. M. Todaro, N. M. Gusmerotti and M. R. De Giacomo (2020). 'The influence of institutional pressures on climate mitigation and adaption strategies', Journal of Cleaner Production, 244, art. 118879.

Deephouse, L. D., W. Newburry and A. Soleimani (2016). 'The effects of institutional development and national culture on cross-national differences in corporate reputation', Journal of World Business, 51, pp. 463-473.

Deloitte (2014). 'Global survey on reputation risk'. Available at https://www2.deloitte.com/content/dam/Deloitte/pl/ Documents/Reports/pl_Reputation_Risk_survey_EN.pdf [accessed 20 August 2020].

Deloitte (2016). 'Reputation matters - developing reputational resilience ahead of your crisis'. Available at https: //www2.deloitte.com/content/dam/Deloitte/uk/Documents/ risk/deloitte-uk-reputation-matters-june-2016.pdf [accessed 20 August 2020]. 
DiMaggio, P. J. and M. W. Powell (1983). 'The Iron Cage revisited: institutional isomorphism and collective rationality in organization fields', American Sociological Review, 48, pp. 147160.

Eccles, R. G. and S. Klimenko (2019). 'The investor resolution', Harvard Business Review, May/June. Available at https:// hbr.org/2019/05/the-investor-revolution [accessed 19 October 2020].

El Ghoul, S. and X. Zheng (2016). 'Trade credit provision and national culture', Journal of Corporate Finance, 41, pp. 475501.

European Social Survey (2016). 'Round 8 survey specification for ESS ERIC member, observer and guest countries', ESS ERIC Headquarters, City University London.

Felbermayr, G. and J. Gröschl (2014). 'Naturally negative: the growth effects of natural disasters', Journal of Development Economics, 111, pp. 92-106.

Fernandes, S. M., A. C. Bornia and L. R. Nakamura (2019). 'The influence of boards of directors on environmental disclosure', Management Decision, 57, pp. 2358-2382.

FleishmanHillard Fishburn (2019). 'Leading with impact: authenticity in a climate of change'. Available at https: //fleishmanhillard-fishburn.ck.page/1a845e7e4d [accessed 19 October 2020].

Gardberg, A. N. (2006). 'Reputatie, reputation, réputation, reputazione, ruf: a cross-cultural qualitative analysis of construct and instrument equivalence', Corporate Reputation Review, $\mathbf{9}$, pp. 39-61.

Glover, J. L., D. Champion, K. J. Daniels and A. J. D. Dainty (2014). 'An institutional theory perspective on sustainable practices across the dairy supply chain', International Journal of Production Economics, 152, pp. 102-111.

González-Benito, J. and Ó. González-Benito (2008). 'A study of determinant factors of stakeholder environmental pressure perceived by industrial companies', Business Strategy and the Environment, 19, pp. 164-181.

Gregory, J. R. (1998). 'Does corporate reputation provide a cushion to companies facing market volatility? Some supportive evidence', Corporate Reputation Review, 1, pp. 288-290.

Hambrick, D. C. and P. A. Mason (1984). 'Upper echelons: the organization as a reflection of its top managers', The Academy of Management Review, 9, pp. 193-206.

Hamilton, L. C. and B. D. Keim (2009). 'Regional variation in perceptions about climate change', International Journal of Climatology, 29, pp. 2348-2352.

Helm, S. (2011). 'Employees' awareness of their impact on corporate reputation', Journal of Business Research, 64, pp. 657-663.

Hoffman, A. J. (2001). 'Linking organizational and fieldlevel analysis', Organization \& Environment, 14, pp. 133156.

Hofstede, G. (1980). Culture's Consequences: International Differences in Work-Related Values. Beverly Hills, CA: Sage.

Hofstede, G. (2001). Culture's Consequences: Comparing Values, Behaviors, Institutions, and Organizations Across Nations, 2nd edn. Thousand Oaks, CA: Sage.

Hofstede, G. and M. H. Bond (1988). 'The Confucius connection: from cultural roots to economic growth', Organizational Dynamics, 16, pp. 4-21.

Hofstede, G., Hofstede, G. J and Minkov, M. (2010). Cultures and Organizations: Software of the Mind, 3rd edn. New York: McGraw-Hill.
Honnold, J. A. (1984). 'Age and environmental concern some specification of effects', The Journal of Environmental Education, 16, pp. 4-9.

Hörner, J. (2002). 'Reputation and competition', The American Economic Review, 92, pp. 644-663.

Howe, P. D., E. M. Markowitz, T. M. Lee, C. Y. Ko and A. Leiserowitz (2013). 'Global perceptions of local temperature change', Nature Climate Change, 3, pp. 352-356.

Khatami, S. H., M.-T. Marchica and R. Mura (2016). 'Rating friends: the effect of personal connections on credit ratings', Journal of Corporate Finance, 39, pp. 222-241.

Kondra, A. Z. and C. R. Hinings (1998). 'Organizational diversity and change in institutional theory', Organization Studies, 19, pp. 743-767.

Kumar, A. (2020). 'Leadership and decision-making: top management team age demographic and environmental strategy', Journal of Management and Organization, pp. 1-17.

Leiserowitz, A. (2006). 'Climate change risk perception and policy preference: the role of affect, imagery, and values', Climatic Change, 77, pp. 45-72.

Lo, A. (2016). 'National income and environmental concern: observations from 35 countries', Public Understanding of Science, 25, pp. 873-890.

Logsdon, M. J. and K. Yuthas (1997). 'Corporate social performance, stakeholder orientation, and organizational moral development', Journal of Business Ethics, 16, pp. 1213-1226.

Lujala, P., H. Lein and J. Ketil Rød (2015). 'Climate change, natural hazards, and risk perception: the role of proximity and personal experience', Local Environment, 20, pp. 489-509.

Meyer, J. W. and B. Rowan (1977). 'Institutionalized organizations: formal structure as myth and ceremony', American Journal of Sociology, 83, pp. 340-363.

Miles, J. S. and G. W. Mangold (2014). 'Employee voice: untapped resource or social media time bomb?', Business Horizons, 57, pp. 401-411.

Mishina, Y., E. S. Block and M. J. Mannor (2012). 'The path dependence of organizational reputation: how social judgement influences assessments of capability and character', Strategic Management Journal, 33, pp. 459-477.

Musteen, M., K. D. Dattal and B. Kemmerer (2010). 'Corporate reputation: do board characteristics matter?', British Journal of Management, 21, pp. 498-510.

Nardella, G., S. Brammer and I. Surdu (2019). 'Shame on who? The effects of corporate irresponsibility and social performance on organizational reputation', British Journal of Management, 31, pp. 5-23.

Oliver, C. (1991). 'Strategic responses to institutional processes', Academy of Management Review, 16, pp. 145-179.

Papadimitri, P., F. Pasiouras, M. Tasiou and A. Ventouri (2020). 'The effects of board of directors' education on firms' credit ratings', Journal of Business Research, 116, pp. 294-313.

Raithel, S. and M. Schwaiger (2015). 'The effects of corporate reputation perceptions of the general public on shareholder value.' Strategic Management Journal, 36, pp. 945-956.

Richard, O., T. Barnett, S. Dwyer and K. Chadwick (2004). 'Cultural diversity in management, firm performance, and the moderating role of entrepreneurial orientation dimensions'. Academy of Management Journal, 47, pp. 255-266.

Roberts, W. P. and R. G. Dowling (2002). 'Corporate reputation and sustained superior financial performance', Strategic Management Journal, 23, pp. 1077-1093. 
Scott, W. R. (1992). Organizations: Rational, Natural, and Open Systems. Englewood Cliffs, NJ: Prentice Hall.

Shi, X. and Z. Xu (2018). 'Environmental regulation and firm exports: evidence from the eleventh Five-Year Plan in China', Journal of Environmental Economics and Management, 89, pp. 187-200.

Soleimani, A., D. W. Schneper and W. Newburry (2014). 'The impact of stakeholder power on corporate reputation: a crosscountry corporate governance perspective', Organization Science, 25, pp. 991-1008.

Spence, A., W. Poortinga and N. Pidgeon (2011). 'The psychological distance of climate change', Risk Analysis, 32, pp. 957 972.

Staw, M. B. and D. L. Epstein (2000). 'What bandwagons bring: effects of popular management techniques on corporate performance, reputation, and CEO pay', Administrative Science Quarterly, 45, pp. 523-556.

Suchman, M. C. (1995). 'Managing legitimacy: strategic and institutional approaches', Academy of Management Review, 20, pp. 571-610.

Walls, J. L. and A. J. Hoffman (2013). 'Exceptional boards: environmental experience and positive deviance from institutional norms', Journal of Organizational Behavior, 34, pp. 253-271.

Walsh, G., V. W. Mitchell, R. P. Jackson and E. S. Beatty (2009). 'Examining the antecedents and consequences of corporate reputation: a customer perspective', British Journal of Management, 20, pp. 187-203.

Wang, S., J. Li and D. Zhao (2018). 'Institutional pressures and environmental management practices: the moderating effects of environmental commitment and resource availability', Business Strategy and the Environment, 27, pp. 52-69.
Weber, E. U. (2016). 'What shapes perceptions of climate change: new research since 2010', Wiley Interdisciplinary Reviews: Climate Change, 7, pp. 125-134.

Weber Shandwick and KRC Research (2020). 'The state of corporate reputation in 2020: everything matters now'. Available at https://www.webershandwick.com/wpcontent/uploads/2020/01/The-State-of-Corporate-

Reputation-in-2020_executive-summary_FINAL.pdf [accessed 20 August 2020].

Winn, M., P. MacDonald and C. Ziestsma (2008). 'Managing industry reputation: the dynamic tension between collective and competitive reputation management strategies', Corporate Reputation Review, 11, pp. 3555.

Wooldridge, J. M. (2010). Econometric Analysis of Cross Section and Panel Data. Boston, MA: MIT Press.

World Economic Forum (2012). Global Risk 2012, 7th edn. Available at http://www3.weforum.org/docs/WEF_GlobalRisks_ Report_2012.pdf [accessed 20 August 2020].

Wright, C. and A. Rwabizambuga (2006). 'Institutional pressures, corporate reputation, and voluntary codes of conduct: an examination of the equator principles', Business and Society Review, 111, pp. 89-117.

Zhang, Q., Z. Yu and D. Kong (2019). 'The real effect of legal institutions: environmental courts and firm environmental protection expenditure', Journal of Environmental Economics and Management, $\mathbf{9 8}$, art. 102254.

Zyglidopoulos, C. S. (2005). 'The impact of downsizing on corporate reputation', British Journal of Management, 16, pp. 253-259.

Chrysovalantis Gaganis is an Associate Professor in Finance, in the Department of Economics at the University of Crete (Greece). His research interests are in the fields of financial institutions and corporate finance. He has co-published nine books and published over 50 papers, appearing in various journals such as Management Science, Journal of Banking \& Finance, European Journal of Operational Research and Journal of Financial Stability, among others.

Panagiota Papadimitri is a Senior Lecturer in Accounting and Financial Management at the University of Portsmouth. Her research interests revolve around the broader area of corporate finance and governance of (non-)financial institutions, with particular focus on incorporating elements of formal and informal institutions to examine their impact on corporate behaviour. Her research papers are published in journals such as the Journal of Corporate Finance, Journal of Business Ethics and Journal of Business Research, among others.

Fotios Pasiouras is Full Professor at MBS, member of FEL (TUC), board member of FEBS and Visiting Professor at the University of Portsmouth. His research interests include risk, performance, corporate governance, regulations and informal institutions. His work has appeared in over 80 papers published in journals like Management Science, Journal of Money, Credit \& Banking, Journal of Banking \& Finance, European Journal of Operational Research, Journal of Business Ethics and Journal of Financial Stability.

Alexia Ventouri is an Associate Professor (Senior Lecturer) in Banking and Finance at King's Business School. Her research areas include empirical finance and banking, corporate finance, performance, risk, the industrial structure of banking and financial regulation. Her publications appear in internationally recognized journals such as the Journal of Banking and Finance, Journal of Business Research, 
Journal of Financial Stability, Journal of Empirical Finance, Journal of Business, Finance and Accounting, among others.

\section{Supporting Information}

Additional supporting information may be found online in the Supporting Information section at the end of the article.

Supplementary Material

(C) 2021 The Authors. British Journal of Management published by John Wiley \& Sons Ltd on behalf of British Academy of Management. 